\title{
Geology and Mineral Resources of the Chitral-Partsan area, Hindu Kush Range, Northern Pakistan
}

GEOLOGICAL SURVEY PROFESSIONAL PAPER 716-G

Prepared in cooperation with the Geological Survey of Pakistan, under the auspices of the U.S. Department of State and the Government of Pakistan

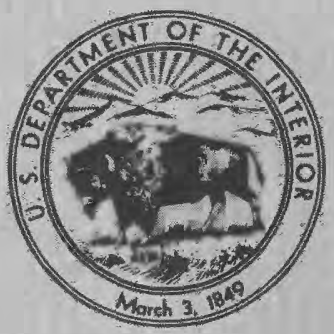





\section{Geology and Mineral Resources \\ of the Chitral-Partsan Area, \\ Hindu Kush Range, \\ Northern Pakistan}

By JAMES A. CALKINS, S. JAMILUDDIN, KAMALUDDIN BHUYAN, and AHMAD HUSSAIN

GE OLOGICAL I NVESTIGATIONS I N PAKISTA N

GEOLOGICAL SURVEY PROFESSIONAL PAPER 716 -G

Prepared in cooperation with the Geological Survey of Pakistan, under the auspices of the U.S. Department of State and the Government of Pakistan

Folded and faulted Devonian through Cretaceous rocks constitute the Hindu Kush range. Antimony-lead ore veins, with associated gold, silver, and copper, are localized along major reverse and thrust faults

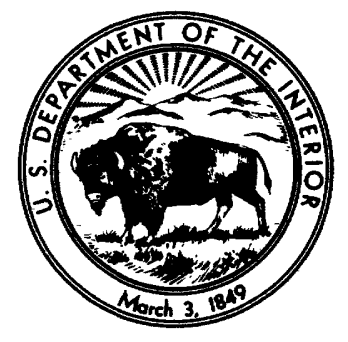




\section{UNITED STATES DEPARTMENT OF THE INTERIOR}

JAMES G. WATT, Secretary

\section{GEOLOGICAL SURVEY}

Doyle G. Frederick, Acting Director

\section{Library of Congress Cataloging in Publication Data}

Main entry under title:

Geology and mineral resources of the Chitral-Partsan area, Hindu Kush range, northern Pakistan.

(Geological investigations in Pakistan) (Professional paper-Geological Survey ; 716-G)

"Prepared in cooperation with the Geological Survey of Pakistan, under the auspices of the U.S. Department of State and the Government of Pakistan."

Bibliography: p.

Supt. of Docs. no.: I 19.16:716-G

1. Geology-Pakistan-Chitral region. 2. Mines and mineral resources-Pakistan-Chitral region. I. Calkins, James Alfred, 1923- II. Pakistan. Geological Survey. III. Title. IV. Series: V. Series: United States. Geological Survey.

Professional paper ; 716-G.

QE295.4G45 555.49'122 80-607067

For sale by the Distribution Branch, U.S. Geological Survey, 604 South Pickett Street, Alexandria, VA 22304 


\section{FOREWORD}

In 1956, the Geological Survey of Pakistan and the U.S. Geological Survey began a cooperative program to intensify the mapping and appraisal of the geological resources of Pakistan. The program was initiated under an agreement dated October 1955 between the Government of Pakistan and the International Cooperation Administration, predecessor of the Agency for International Development, U.S. Department of State. It included joint geological reconnaissance of unmapped areas, detailed mapping and appraisal of mineral districts, and development of facilities and staff to increase the capacity of the Geological Survey of Pakistan.

This volume entitled "Geological Investigations in Pakistan" is intended to present some of the more significant results of the cooperative program in Pakistan, which extended from 1956 to 1970. It consists of papers that have been prepared by U.S. Geological Survey geologists and by their counterparts in the Geological Survey of Pakistan, summarizing the investigations believed to be most important for those interested in the geology and resources of Pakistan. More detailed information from these investigations, as well as reports from other studies made during the program, are available from the Geological Survey of Pakistan in Quetta. Much of the regional geological information obtained during this program, and from surveys made earlier, was summarized in a new Geological Map of Pakistan prepared cooperatively and published by the Geological Survey of Pakistan in 1964.

The cooperative program in Pakistan, which directly involved the services of about 110 professional personnel from Pakistan and 43 from the United States, operated successively under the direction of four Directors-General of the Geological Survey of Pakistan and three Chiefs of Party appointed by the U.S. Geological Survey. Program directors for Pakistan were E. R. Gee (195659), N. M. Khan (1959-64), A. F. M. M. Haque (1964-69), and A. M. Khan (1969-70). United States participation was supervised by J. A. Reinemund (1956-63), M. G. White (1963-66), and D. L. Rossman (1967-70), each of whom also served as senior geologic consultant to the Director-General.

Geologic specialists provided by the U.S. Geological Survey were supplemented by four mining engineers from the U.S. Bureau of Mines, who provided collateral assistance to the Pakistan Department of Mineral Development, and by a drilling specialist and an administrative specialist from the Agency for International Development. The Geological Survey of Pakistan, through the Ministry of Industries and Natural Resources, provided counterpart personnel facilities, and services for the program, and arranged cooperative support from the Pakistan Department of Mineral Development, as well as from the Pakistan Industrial Development Corporation, Pakistan Council of Scientific and Industrial Research, and other agencies concerned with resource development. 
This program would not have been possible without the excellent support of all agencies involved, both in Pakistan and the United States. The geological information and institutional growth obtained through this program should contribute significantly toward orderly economic and scientific development in one of Asia's largest and newest nations.

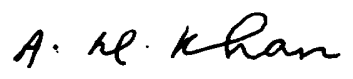

Abdul Mannan Khan, Director-General Geological Survey of Pakistan

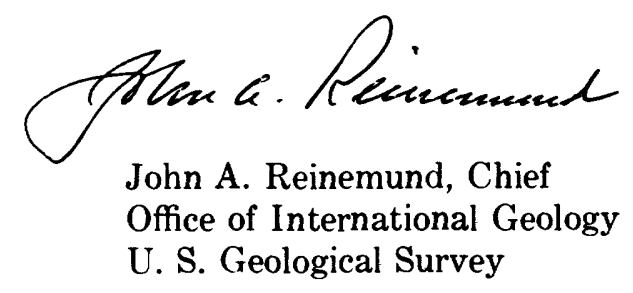




\section{CONTENTS}

\begin{tabular}{|c|c|c|}
\hline Page & & Page \\
\hline G 1 & Mineral deposits-Continued & \\
\hline 1 & Veins containing antimony, lead, and copper-Continued & \\
\hline 1 & Kamal Gol mine & G23 \\
\hline 3 & Bakht Gol mine & 26 \\
\hline 3 & Reserves & 26 \\
\hline 5 & Partsan area & 27 \\
\hline 5 & Partsan antimony mine & 27 \\
\hline 6 & East rim antimony locality & 27 \\
\hline 6 & Copper-antimony showings & 27 \\
\hline 6 & Shoghot-Madashil area & 28 \\
\hline 6 & Shoghot locality & 28 \\
\hline 6 & Madashil locality & 28 \\
\hline 7 & Prince Burhanuddin locality & 28 \\
\hline 7 & Kukil-Gahirat area & 29 \\
\hline 8 & Kukil locality & 29 \\
\hline 8 & Gahirat locality & 29 \\
\hline $\begin{array}{l}8 \\
9\end{array}$ & Drosh-Shishi Valley area & 29 \\
\hline $\begin{array}{l}9 \\
9\end{array}$ & Gawuch Gol locality & 29. \\
\hline 9 & Kaldam Gol locality ___ & 29 \\
\hline 9 & Copper localities in mafic rocks and greenschist & 29 \\
\hline 10 & Drosh-Shishi Valley area & 30 \\
\hline 10 & Koghozi area & 30 \\
\hline 11 & Momi locality _._______ & 30 \\
\hline 11 & Other mineralized localities & 31 \\
\hline 11 & Kafiristan area & 31 \\
\hline 11 & Drosh-Chitral road & 31 \\
\hline 12 & Muzhigram & 31 \\
\hline 12 & Shoghot & $\mathbf{3 1}$ \\
\hline 12 & Mogh & 31 \\
\hline 13 & Hot Springs area & 31 \\
\hline 13 & Nonmetallic mineral resources & 31 \\
\hline 13 & Marble, limestone, and dolomite & 31 \\
\hline 13 & Granite building stone & 32 \\
\hline 14 & Pegmatite & 32 \\
\hline 14 & Talc & 32 \\
\hline 17 & Phosphate & 32 \\
\hline 17 & Conclusions and recommendations & 33 \\
\hline 23 & References cited & 33 \\
\hline
\end{tabular}

\section{ILLUSTRATIONS}



Plate 1. Geologic map and sections, Chitral-Partsan area, Pakistan

In pocket

2. Regional geologic map of the Chitral-western Gilgit area, Pakistan

FIGURE 1. Index map of Pakistan showing location of the mapped area

2. Stratigraphic nomenclature used in six reports on the Chitral-Gilgit area

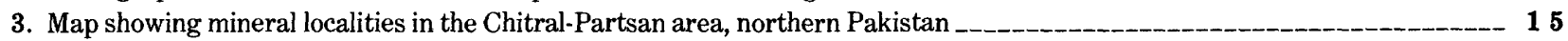

4. Map showing locations of analyzed rock and ore samples, Chitral-Partsan area, northern Pakistan

5. Tape-compass survey map of Krinj (Kamal Gol) mine area, Chitral Mining Co., Ltd. _._______ 2

6. Plan map of the Krinj (Kamal Gol) Mine, Chitral Mining Co., Ltd. 
CONTENTS

\section{TABLES}

Page

TABLE 1. Semiquantitative spectrographic analyses of samples from the Chitral-Partsan area, Pakistan

In pocket

2. Partial chemical analyses of samples from the Chitral-Partsan area 


\title{
GEOLOGY AND MINERAL RESOURCES OF THE GHITRAL-PARTSAN AREA, HINDU KUSH RANGE, NORTHERN PAKISTAN
}

\author{
By James A. Calkins, S. Jamiluddin, ${ }^{1}$ Kamaluddin BhuYan, ${ }^{1}$ and Ahmad Hussain ${ }^{1}$
}

\begin{abstract}
This report is based upon field investigations covering an area of about 1,400 square miles $(3,626 \mathrm{sq} \mathrm{km})$ in the Hindu Kush Mountains of Chitral State in northern Pakistan and also includes a discussion of geological questions relating to an area of about 8,000 square miles $(20,720 \mathrm{sq} \mathrm{km})$ in the Chitral-Gilgit area. The area is extremely rugged; local relief is more than 8,000 feet $(2,438$ meters) over most of the area and commonly reaches 10,000 feet $(3,048$ meters). Many peaks are higher than 17,000 feet (5,182 meters), and Tirich Mir, 8 miles (12.9 $\mathrm{km}$ ) north of the mapped area, is 25,263 feet (7,700 meters) high.

The mapped area includes the following units: Devonian unit; Sarikol Shale (Devonian to Carboniferous); a broad belt of metamorphic rocks of Devonian to Jurassic age; Reshun Formation, a volcanic greenstone unit, a limestone and phyllite unit, a greenschist unit, and the Chitral Slate-all of Cretaceous age. Elongate bodies of granite (Cretaceous) underlie large parts of the area. Of stratigraphic interest are (1) the lateral facies change of the Reshun Formation from fossiliferous conglomeratic red shale and phyllite at Reshun, to marble in the Kafiristan area, and (2) the determination of a Cretaceous age for the Chitral Slate, which formerly was considered to be of Paleozoic age.

Structurally, the mapped area is characterized by a system of folds overturned toward the east and south. This fold pattern marks the regional trend of the Hindu Kush Range, from north in the southwestern part of the area to east-northeast in the eastern part. Several reverse and thrust faults separate belts of rocks of Cretaceous age from belts of older rocks.

Metallic deposits in the area include (1) veins containing antimony, lead, and copper with associated gold, silver, and tin; (2) copper localities in mafic rocks and greenschist; and (3) miscellaneous showings, mainly of copper. Antimony has been mined on a small scale at Krinj since 1939. The places of high mineral potential are the vein-type deposits along the fault zones in the Awireth Gol-Shoghot-Madashil area, the Krinj mine area, and in the Shishi Valley area. Along these faults the largest showings of copper, lead, and antimony are found, and in the Awireth Gol locality the lead ore contains large amounts of gold and silver.

Nonmetallic mineral deposits include limestone, marble, dolomite, granite, pegmatite, and talc. No commercial limestone industry exists

${ }^{1}$ Geological Survey of Pakistan, Quetta.
\end{abstract}

in the Chitral area. However, limestone and marble are used locally for building stone. Granite is also used locally for building stone. Mica and beryl are mined on a small scale from pegmatites 15 miles $(24 \mathrm{~km})$ northwest of the mapped area.

\section{INTRODUCTION}

\section{LOCATION, ACCESSIBILITY, AND PHYSICAL FEATURES}

Field investigations were conducted in an area of about 1,400 square miles $\left(3,626 \mathrm{~km}^{2}\right)$ in the remote Hindu Kush Mountains of Chitral State in the northern part of Pakistan. The boundaries of the area extend from the town of Drosh on the south to the southern slopes of Tirich Mir on the north, and from the Pakistan-Afghanistan border on the west to long. $72^{\circ}$ on the east (fig. 1 , area A). Chitral Town, 130 airline miles $(209 \mathrm{~km})$ or 200 miles by road $(332 \mathrm{~km})$ north of Peshawar, is in the approximate center of the area. As an adjunct to the specific area investigated, this report also discusses geological questions relating to an area of approximately 8,000 square miles $\left(20,720 \mathrm{~km}^{2}\right)$ in the greater Chitral-Gilgit region (fig. 1, area $\mathrm{B}$ ).

Access to Chitral from the more populous districts in the south is difficult and uncertain. A jeep road connecting Chitral with points south is open about 5 months of the year-usually from late June until mid-November. The road crosses Lawari Pass, 25 miles $(40.2 \mathrm{~km})$ south of Drosh, and the pass is closed by snow during the winter months. Scheduled air service connects Chitral with Peshawar, 130 airline miles $(209 \mathrm{~km})$ to the south, but the flights are often cancelled because of bad weather. Northward from Chitral, jeep roads extend for short distances up the Lutkho and Mastuj Rivers. Both these roads were washed out during the summers of 


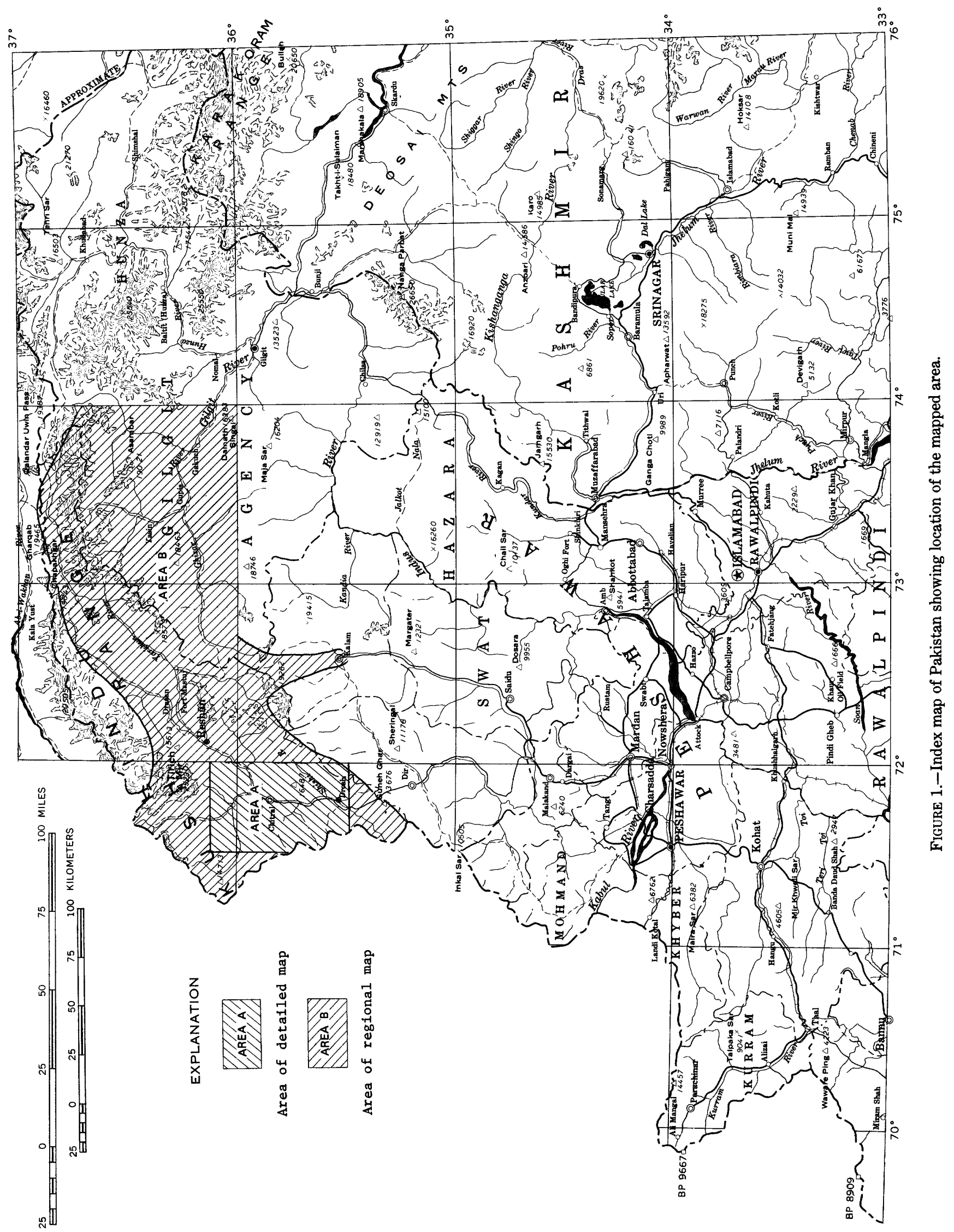


1968 and 1969, when most of the fieldwork was done. Two side roads include a forest road up the Shishi River, which in 1968 was completed for 6 miles to Tar Village, and a road 5 miles long up Birir Gol.

Rugged mountains and deep V-shaped canyons characterize the area. The only flatlands are the minor terraces and narrow floodplains along the main rivers. The area is drained by the south-flowing Chitral River and its two main tributaries, the Lutkho and the Mastuj Rivers. Altitudes range from $4,000-6,000 \mathrm{ft}(1,219-1,828 \mathrm{~m})$ on the main rivers to $15,000-16,000 \mathrm{ft}(4,572-4,877 \mathrm{~m})$ along the ridgelines. Local relief commonly is greater than $8,000 \mathrm{ft}(2438 \mathrm{~m})$, and in places it is greater than $10,000 \mathrm{ft}(3,048 \mathrm{~m})$. From Chitral Town, for example, the valley sides rise from $4,801 \mathrm{ft}(1,463 \mathrm{~m})$ at Chitral to $15,321 \mathrm{ft}(4,670 \mathrm{~m})$ at Jahanam Peak 11 miles $(17.6 \mathrm{~km})$ to the east, providing a local relief of $10,520 \mathrm{ft}(3,206 \mathrm{~m})$. Some peaks are more than $17,000 \mathrm{ft}(5,182 \mathrm{~m})$ high, and Tirich Mir, 8 miles north of the area, is $25,263 \mathrm{ft}$ ( 7,700 m) high.

\section{PURPOSE AND SCOPE OF REPORT}

This investigation was part of a Mineral Investigation and Development Program sponsored by the Government of Pakistan and the Agency for International Development, U.S. Department of State, under PASA NESA 30-00. The primary aim of this survey was to study the metallic mineral deposits and showings of the Chitral area. Many mineral localities have been reported from the Chitral area, including copper, lead, antimony, arsenic, mica, and beryl, and some mining is being done. Most of the previous information on the mineral showings consists of brief on-the-spot descriptions without benefit of laboratory assays and most of this information is unpublished. Therefore, it seemed desirable to conduct a study of wider scope so as to obtain more complete information on the nature, content, extent, and potential of the mineral deposits in the area.

As part of the fieldwork, all previously reported mineral showings and many new ones were located, studied, and sampled; the Krinj antimony mine was studied underground and on the surface, and samples were systematically collected. As a supplement to the mineral studies, numerous reconnaissance traverses were made to collect geologic information throughout the area and beyond the map area as far as Reshun.

Laboratory work included spectrographic and partial chemical analyses of mineralized samples and microscopic study of thin sections of rock collected throughout the area.

In conjunction with the mineral study, a secondary aim was to assemble as much geological information as possible to provide the geologic background needed to assess the nature and potential of the mineral deposits.
The geologic map of the area investigated is shown on plate 1 . In addition, a regional geologic map of the Chitral-Gilgit region was compiled as an aid in relating the geology of the Chitral area to the larger regional picture. This regional map (pl. 2) covers an area of about 8,000 square miles $\left(20,720 \mathrm{~km}^{2}\right.$ ) (about the size of Massachusetts) of high and rugged mountain country. The six references used in this compilation (see inset, pl. 2 ) are in disagreement in many places, and combining this information into one map required considerable modification and interpretation. Stratigraphic nomenclature as used in each of the six references is shown in figure 2. Most of the source maps available are reconnaissance strip maps along the line of traverse. Although the resulting compilation contains numerous gaps and inconsistencies, it nevertheless places the mapped area of this report in its regional context and brings together the results of six reports which are either unpublished or not readily available.

\section{FIELDWORK AND ACKNOWLEDGMENTS}

The first fieldwork was done from October 15 to November 15, 1967, by J. A. Calkins and Mahmooduddin Ahmed. As jeep transport was not then available, the work was limited to the area of Rumbur and Bumboret valleys (Kafiristan) and to the area around Krinj. Fieldwork was resumed from July until November 1968, and a 4-week field check was made in May and June 1969. Calkins was accompanied by Jamiluddin during July and August 1968. Kamaluddin Bhuyan joined the party in late August, followed in early September 1968 by Ahmad Hussain. During September and October, two parties operated in the field, during which time Calkins and Hussain worked in the northwestern part of the area while Jamiluddin and Kamaluddin covered the area east of the Chitral River. The field check in 1969 was done by Calkins and Kamaluddin, and included several days of investigations in the Reshun area. Whenever possible, the field parties operated out of State resthouses, but in the many remote areas they stayed in small mountain villages.

Base maps used for the fieldwork were the Survey of Pakistan 1:126,720 topographic sheets 38-M/NE, $37-\mathrm{P} / \mathrm{SE}$, and $42-\mathrm{D} / \mathrm{NW}$, all enlarged to a scale of $1: 96,000$.

This work was done as part of a cooperative program between the Geological Survey of Pakistan and the U. S. Geological Survey under the auspices of the Government of Pakistan and the Agency for International Development, U. S. Department of State. The authors wish to acknowledge the full support of Captain Abdul Qayum Khan, Political Agent, Chitral; Mr. Wazir Ali Shaw, Finance Minister of Chitral; Mr. Moinuddin, Superintendent of Police; and numerous members of the 


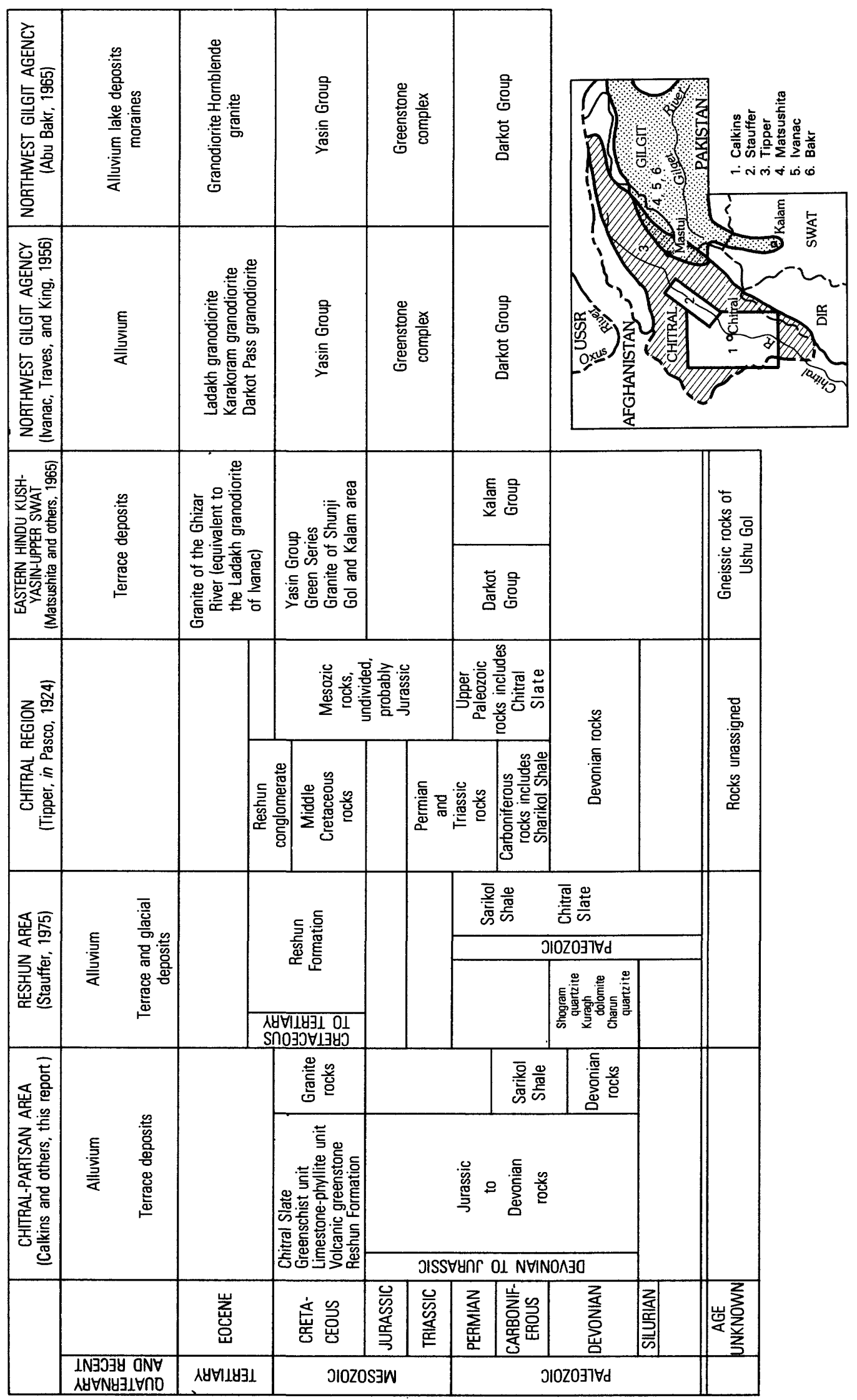


Chitral Police. The authors also appreciate the hospitality and assistance given by Mr. A. H. Siddiqui, Resident Geologist, Chitral Mining Company; Major (Prince) S.K.A. Mulk; Colonel (Prince) Khushwaqt-ul-Mulk; Prince Asad ur-Rahman; and Prince Burhanuddin.

\section{PREVIOUS WORK}

The first geological information from Chitral is that of Lieutenant I. H. Grant, British India Colonial Forces, who collected some Early Devonian trilobites and brachiopods from Showar Shur in the upper Yarkhun Valley, 140 miles $(225 \mathrm{~km})$ northeast of Chitral. These fossils were described by F.R.C. Reed of the Geological Survey of India (1911, p. 86-100). In this paper, Reed (p. 1) mentions a series of fossils that were collected earlier by Captain B.E.M. Gurdon from near Reshun, 30 miles $(48 \mathrm{~km})$ northeast of Chitral, and described by McMahon and Huddleston (1902). These fossils were determined to be of Late Devonian age.

In 1914, H. H. Hayden, Director of the Geological Survey of India, returned to England on leave, traveling on foot, via Chitral, Gilgit, and the Pamirs of Russia. His report, in the form of a trip log, contains the first information on the general geology of the Chitral area (Hayden, 1915, p. 271-335). He found several fossil localities, including localities at Drosh, Reshun, Shogram, 1 mile upstream from Reshun, and many more to the northeast. These collections were described by Reed in two excellent memoirs on the Devonian and Carboniferous fossils of Chitral and the Pamirs (Reed, 1922, 1925).

The first geological mapping in Chitral was done by Tipper during the three field seasons of 1921 through 1923. He completed the reconnaissance of most of Chitral State at a scale of 1 inch to 4 miles, but unfortunately, a report of this work has never been published. Some information on Tipper's work is contained in the annual reports of the Geological Survey of India (Fermor, 1922, p. 55-57; Pascoe, 1923, p. 37-39; Pascoe, 1924 , p. 44-48). In addition, a copy of his map is on file at the Geological Survey of Pakistan, Quetta. This map shows the generalized boundaries of the various rock systems, but contains no information on the structure or on the individual lithologic units or formations.

The latest geological work was done in 1964 by K. W. Stauffer in the Reshun area. His report (Stauffer, 1975) discusses the geology of a rectangular area of 160 square miles $\left(414 \mathrm{~km}^{2}\right)$ extending 27 miles $(43.4 \mathrm{~km})$ along the Mastuj River, from the edge of the mapped area of this report to Buni, 12 miles $(19.3 \mathrm{~km})$ northeast of Reshun.

Numerous short reports, mostly unpublished, have been written on the mineral deposits of the area. These include three file reports on the antimony mines at Krinj
(Sondhi, 1942; Nath, 1944; Crookshank, 1951). Brief descriptions of the mineral occurrences of Chitral State are contained in unpublished file reports by S. I. Ali (1951) and S. T. Ali (1949). The latest compilation on the mineral occurrences in Chitral was done in 1965 by M. G. White 1975.

\section{GEOLOGIC SETTING}

The mapped area (pl. 1) is on the southern flanks of the Hindu Kush range, which forms the western segment of the broad mountain arc of the greater Himalayan mountain system. The regional geologic map (pl. 2) shows the regional geologic and tectonic trends for many miles beyond the area of plate 1 .

From the northeastern trend of the Hindu Kush range in the mapped area, the high peaks of the Himalayan mountain system swing in a great arc, first to the east through Yasin, then to the southeast through Gilgit, Kashmir, and across northern India. A system of outcrop belts of various rock types, as well as several reverse and thrust faults, help to define this arcuate pattern. The Hindu Kush merges with the Karakoram range of Gilgit and Kashmir, which in turn is indirectly connected to the Ladakh range, the Great Himalaya, and other individual ranges of Kashmir and northern India.

The rocks in the mapped area of plate 1 range in age from Devonian to Cretaceous and consist mainly of regionally metamorphosed rocks of low to medium grade, and granite intrusions. A wide, north-northeasttrending belt of slate, called the Chitral Slate, underlies Chitral Valley, and is flanked on both sides by bands of marble and other types of metamorphic rocks. The metamorphic rocks, in turn, are flanked by granite bodies of Cretaceous age, which crop out in the western and southeastern edges of the area. Other granite bodies are found within the metamorphic rocks.

The metamorphic rocks are mainly those of the greenschist facies of regional metmorphism, increasing to the amphibolite facies as the granite bodies are approached. Rocks of low metamorphic grade include slate, marble, chlorite-quartz schist, chloritoid-sericitequartz schist, volcanic greenstone, graphitic schist, and other types. Higher-grade metamorphic rocks of the amphibolite facies and its equivalent include garnet-biotite schist, garnet-biotite-staurolite schist, amphibolite, quartz-hornblende schist, and other types. Metamorphic index minerals higher than staurolite have not been found.

Beginning at Partsan and extending northeastward beyond Reshun, regional metamorphism decreases rapidly and numerous fossil collections, made many years ago, establish Devonian, Carboniferous, Permian: and Cretaceous ages for the limestone, shale, and con- 
glomerate of that area. Another useful fossil locality is found in slightly metamorphosed Cretaceous rocks about 3 miles $(4.8 \mathrm{~km})$ south of Drosh near the south edge of the map area.

Structurally, the mapped area of plate 1 is characterized by a system of folds overturned toward the east and south. An elongate synclinal belt, itself isoclinally folded internally, follows the Chitral and Mastuj Rivers and is marked by the Chitral Slate, which is found in the trough of the syncline. On a regional scale, as seen on plate 2 , the elongate fold pattern results in a system of outcrop bands of differing rock types. Several reverse and thrust faults separate belts of Cretaceous rock units from belts of older rocks. Elongate bodies of granite are found on the high ridge lines. The shape and distribution of these granite bodies indicate that they may represent anticlinal domes.

\section{STRATIGRAPHY}

The most widespread unit mapped is a sequence of Devonian to Jurassic rocks in the western and northern parts of the mapped area (pl. 1). These rocks are metamorphosed and unfossiliferous over much of the mapped area and are undivided on the map except for a marble unit and an amphibolite unit.

From Partsan, a zone of essentially nonmetamorphosed rocks extends northeastward for many miles beyond the mapped area and provides information on stratigraphy and paleontology. Within this zone, a Middle to Upper Devonian unit and the black Sarikol Shale (Devonian to Carboniferous), are shown separately on plate 1 and on plate 2. Devonian and Permian fossils also were found in the undivided Devonian to Jurassic sequence.

Rock units mapped as Cretaceous include a wide synclinal belt forming much of Chitral Valley and a narrower belt extending from Drosh northeastward along the Shishi River. In the Chitral Valley, the Cretaceous rocks are divided into the Reshun Formation, a volcanic greenschist unit, and the Chitral Slate. The Cretaceous rocks in the Drosh area are divided into the Reshun Formation, a volcanic greenstone unit, and a limestone and phyllite unit.

\section{DEVONIAN ROCKS}

\section{DEVONIAN UNIT}

A sequence of Devonian rocks, informally called the Devonian unit, extends from the Reshun fault near Partsan northeastward along the mountain ridges to the edge of the mapped area of plate 1 . Work done in this area indicates that the Devonian unit forms the core of an overturned anticline, called the Partsan anticline. As shown on plate 2 , the Devonian unit continues northeastward through the Reshun area, as mapped by Stauffer (Stauffer, 1975). Beyond Reshun, the Devonian unit extends all the way to Baroghil Pass on the basis of work by Tipper (in Pascoe, 1924, p. 45-48) and by Hayden (1915).

Within the area of plate 1 , the Devonian unit consists mainly of dolomitic limestone with beds of brownweathering dolomitic quartzose sandstone, calcareous black shale, and few beds of volcanic tuff. On the northeast-trending ridge 1 mile $(1.6 \mathrm{~km})$ south of Pasti, a 5 -foot $(1.52 \mathrm{~m})$ bed of gray dolomitic limestone yielded rugose corals of Devonian age. These corals, identified by C. W. Merriam and W. J. Sando, U. S. Geological Survey, include the following genera:

Hexagonaria sp. cf. $H$. rohrinsis Glinski, 1955, Middle Devonian.

Tabulophyllum sp. indet., Middle and Late Devonian. Disphyllum or Actnophyllum sp. indet., Devonian. Devonian corals, also identified by Merriam and Sando, were found in a second locality 1 mile $(1.6 \mathrm{~km})$ upstream from Pasti, west of the Pasti fault. This locality, which is in the area mapped as Devonian to Jurassic, undivided, yielded specimens of Disphyllum of Actnophyllum sp. indet., from limestone beds similar to those of the firstmentioned locality.

In the Reshun area, Stauffer (written commun.,1966) subdivided the Devonian into three units, but they are mapped as one unit on plate 2. Fossils from the Reshun area collected by Hayden (Reed, 1922, p. 3-4) and Stauffer (written commun., 1966) include corals and brachiopods of Devonian age. Additional Devonian collections were made by Tipper in the upper Turikho Valley near Warkup, 4 miles $(6.4 \mathrm{~km})$ south of Rain, and in the Owir Gol (Gorge) upstream from Barum.

\section{DEVONIAN TO CARBONIFEROUS ROCKS}

\section{SARIKOL SHALE}

The Sarikol Shale, named by Hayden $(1915$, p. 300$)$ is a thick sequence of black shale found in the Sarikol range of the eastern Pamirs of Russia. Lithologically, similar shale and quartzite forming the ridge north of Reshun (called Kosht ridge) were also thought to be Sarikol Shale by Hayden (in Pascoe, 1924, p. 47). During his 1923 field season, Tipper (in Pascoe, 1924, p. 47) traced a broad belt of shale, which he considered to be the Sarikol Shale, from Kosht Ridge, north of Reshun, northeastward along the upper Turikho Valley as far as Shah Jinali Pass, a distance of about $98 \mathrm{~km}$. Tipper, however, mapped on the basis of age (for example, Devonian period) rather than rock formations. Therefore, Tipper does not show the Sarikol Shale as a separate unit. Stauffer (written commun., 1966) worked out the detailed distribution of the Sarikol Shale in the Reshun area. 
In the mapped area (pl. 1), the Sarikol Shale overlies the Devonian unit in two parallel outcrop belts along both limbs of the Partsan anticline. The southeastern belt is less than a quarter of a mile wide and extends for only a few miles. The northwestern belt underlies the entire Partsan basin, a width of about 3 miles $(4.8 \mathrm{~km})$. From the Partsan basin, the belt extends northeastward through Pasti and narrows to about $1,000 \mathrm{ft}(305 \mathrm{~m})$ at the eastern edge of the mapped area (pl. 1). The northwestern outcrop belt continues into the Reshun area where, as shown by Stauffer (written commun, 1966), it occupies a wide zone on the northwest side of the Mastuj River. The Sarikol Shale is known from Tipper's work to extend far beyond the Reshun area, but he did not map it as a separate unit.

The Sarikol Shale consists mainly of soft, thinly laminated, black shale and micaceous phyllite. Beds 2 to 4 inches $(5-10 \mathrm{~cm})$ thick of brown-weathering dolomite and gray limestone are found in places, as are a few thin beds of brown-weathering calcareous sandstone.

As good fossil localities have not been found in the Sarikol Shale, the age of this unit is not conclusively known. South of Pasti, the Sarikol Shale overlies rocks of Middle to Late Devonian age. On the steep slope 2 miles $(3.2 \mathrm{~km})$ north of Pasti and east of the Pasti fault, the Sarikol Shale is overlain by a thick, undisturbed sequence of limestone and shale, one bed of which contains Permian fusulinids, as determined by R. C. Douglass, U.S. Geological Survey. This limestone bed of known Permian age is, however, about 1,800 ft (549 m) above the Sarikol Shale. Near Gokhten Girri Pass, between Pasti and Partsan, a collection of poorly preserved brachiopods suggests a Devonian or early Carboniferous age. The fossils, examined by R. E. Grant, U.S. Geological Survey, and A. J. Boucot, Oregon State University, include Chonetes (?), rhynchonellids, and a spiriferid. Hayden (in Pascoe, 1924, p. 47) suggested an early Carboniferous age for the Sarikol Shale and Tipper (in Pascoe, 1924, p. 47) suggested that it is Late Devonian. On the basis of the above information, the Sarikol Shale is considered to be Late Devonian or Carboniferous in age.

\section{DEVONIAN TO JURASSIC ROCKS}

Devonian to Jurassic rocks include a wide variety of metamorphic and sedimentary rocks which are undivided on the geologic maps (pls. 1 and 2); they underlie the large area in the western and northern parts of the mapped area of plate 1. Three additional outcrop belts in the eastern part of the mapped area (pl. 1) also are mapped as Devonian to Jurassic.

Regionally, the Devonian to Jurassic rocks underlie two areas (pl. 2). One outcrop area is west and north of the Reshun fault and extends from Kafiristan to Shah Jinali Pass, 120 miles $(193 \mathrm{~km})$ to the northeast. The other area occupies parts of a continuous belt extending from Drosh on the southwest to the Ishkuman River (pl. 2 , eastern edge).

Rocks are mainly metamorphic in the Kafiristan, Hot Springs, and Shoghot areas, and in the three outcrop belts shown in the southeastern part of plate 1. Beginning at Partsan, however, metamorphism decreases abruptly, and sedimentary rocks containing Devonian and Permian fossils are found. Metamorphism also decreases in the upper Arkari valley where Tipper (in Pascoe, 1923, p. 39) found fossils of Mesozoic, probably Jurassic, age.

\section{METAMORPHIC ROCKS}

Because of the effects of metamorphism, the Devonian to Jurassic rocks in the Kafiristan-Hot Springs-Shoghot area are unfossiliferous, and their subdivision into specific time-stratigraphic units is not yet possible. These rocks consist of a wide variety of argillaceous and calcareous sedimentary and some volcanic rocks that have been metamorphosed to greenschist, calcareous schist, marble, phyllite, and other rock types. This broad group of metamorphic rocks is undivided on the map except for a belt of marble in the Hot Springs-Besti area and an amphibolite unit in the Momi area.

In the Kafiristan area, the rocks consist of green and brown phyllite, black argillite, green chlorite-quartz schist, beds of laminated tuffaceous greenstone and greenstone conglomerate, and beds of black graphitic limestone. Along the Lutkho River, the rocks show the effects of gradually increasing metamorphism, ranging from fine-grained greenschist and black phyllite at Shoghot to staurolite schist at Hot Springs.

In the Besti area, the rocks consist of a monotonous series of low-grade fine-grained schists characterized by their content of carbonaceous or graphitic material. Individual rock types include chloritoid-quartz schist, spotted sericite schist, and biotite-quartz schist-all containing graphite and carbonaceous material. North of the mapped area, in the upper Arkari valley, Tipper (in Pascoe, 1923, p. 39) reports that "*** the schists are much less metamorphosed and become comparatively soft shaly beds." Near Nuqsan An (Pass) he found "a complete belemnite $* * *$ and fragments of two others $* * * "$ and concluded (p. 39) that the rocks in that area were in part " $* * *$ Mesozoic and probably Jurassic in age."

A prominent band of marble and calcareous phyllite extending from Hot Springs to Besti is shown as a separate unit on the map. At the Lutkho River, the marble is cut off by the granite and is highly metamorphosed 
to diopside marble at this place. Northward, where the grade of metamorphism decreases, the unit changes to light-tan sericitic marble, light greenish-gray calcareous schist, and brown siliceous marble.

A northeast-trending belt of layered amphibolite, mapped separately, is located in Arkari Gol between Momi and Muzhigram (pl. 1). The amphibolite unit is mainly a monotonous series of laminated, dark-green, fine-grained hornblende-plagioclase schists.

Two outcrop belts of metamorphic rocks in the Shishi Valley area and one in the upper part of Koghozi Gol are placed with the Devonian to Jurassic rocks. These outcrop belts consist of an interbedded sequence of gray and black thin-bedded marble, chlorite-quartz schist, black and brown phyllite, and calcareous phyllite. Toward the granite bodies, which are found in the mountains on both sides of Shishi Valley, these rocks undergo a progressive metamorphic change to amphibolite and interlayered garnet-bearing granite and amphibolite.

\section{SEDIMENTARY ROCKS}

Within the distance of 6 miles $(9.6 \mathrm{~km})$ from the Lutkho River to the Pasti area, the metamorphic rocks of the Kafiristan-Hot Springs-Shoghot area pass into the sedimentary and volcanic rocks of the Partsan-Pasti area. This zone of little or no metamorphism is bounded along its southern margin by the Krinj fault and extends from Partsan northeastward at least to Buni, 12 miles $(19 \mathrm{~km})$ northeast of Reshun, and, except for interruptions due to granite intrusions, it possibly extends all the way to the vicinity of Baroghil Pass (see pl. 2) where Devonian fossils were collected many years ago (Reed, 1911, p. 86-100; Reed, 1922, p. 80-81).

Investigations between Partsan and Pasti were sufficient to identify and delineate the Devonian unit and the Sarikol Shale, which have been described in preceding pages. However, time was not available to complete the investigation of the area between Beshgram and Owir Gol (gorge), and these rocks are mapped as undivided Devonian to Jurassic rocks. Devonian corals found in dolomitic limestone 1 mile $(1.6 \mathrm{~km})$ west of Pasti village confirm the Devonian age for some of the rocks in this undivided unit. Tipper (in Pascoe, 1924, p. 47) also reported Late Devonian corals in Owir Gol 4 miles (6.4 $\mathrm{km}$ ) north of Pasti. On the steep slope north of Pasti and east of the Pasti fault, the rocks, consist of an undisturbed and well-exposed sequence of various types of sedimentary rocks including limestone, dolomite, sandstone, and shale. Fusulinids of Permian age, as identified by R. C. Douglass, U. S. Geological Survey, were found in gray limestone near the top of the ridge, 1,800 $\mathrm{ft}(548 \mathrm{~m})$ above the Sarikol Shale. This meager information raises the possibility that a complete stratigraphic section from Devonian to Permian might exist on this steep slope north of Pasti.

\section{CRETACEOUS ROCKS}

RESHUN FORMATION

The Reshun Formation was originally named the Reshun conglomerate by Hayden (1915, p. 283-285), for the conglomerates near the village of Reshun (pl. 2). The Reshun Formation forms three outcrop belts in the mapped area of plate 1; one on the west side of Chitral Valley, a second on the east side of Chitral Valley, and a third following the northeast trend of Shishi Valley.

As far north as the Lutkho River, the western outcrop belt is in gradational contact with the overlying Chitral Slate; northeast of the Lutkho River, the contact with the Chitral Slate is a fault. The western contact, with Devonian to Jurassic rocks, is a fault as far south as Birir Gol in the Kafiristan area, beyond which, except for a few sheared segments, it is a depositional sedimentary contact. Possibly, the contact between the Reshun Formation and the Devonian to Jurassic rocks is an unconformity which has been largely obscured by later faulting. The outcrop belt on the east side of Chitral Valley is in gradational contact with the overlying greenschist unit and the eastern side is faulted against granite and undivided strata of Devonian to Jurassic age. In Shishi Valley, the Reshun Formation forms a gradational contact with the overlying Cretaceous volcanic greenstone unit; the eastern contact is a prominent fault zone.

The Reshun Formation consists of marble, calcareous phyllite, red phyllite, conglomeratic phyllite, and brownweathering conglomerate. 'T'he outcrop belt on the west side of Chitral Valley is made up mainly of marble, which forms a high, generally unscalable ridge. Northeast of the Lutkho River, beds of red phyllite are increasingly abundant in the marble, and on the nearly vertical cliffs near peak 11,884 (see pl. 1), red phyllite can be seen to make up about half the formation. Eastward, the marble passes laterally into conglomeratic red phyllite and conglomerate, which continues beyond the mapped area of plate 1. The outcrop belt on the east side of Chitral Valley consists to two prominint bands of marble separated by a wide zone of interbedded marble, calcareous phyllite, and a small amount of black phyllite. In Shishi Valley, the Reshun Formation is mainly laminated red phyllite with a few beds of conglomeratic red phyllite.

The Reshun Formation has long been known to be of Cretaceous age, on the basis of the foraminifer $\mathrm{Or}$ bitolina found in limestone cobbles at Reshun (Hayden, 1915, p. 284-286; Stauffer, written commun., 1965). The Reshun Formation is equivalent to the Yasin Group of Early Cretaceous age (Ivanac and others, 1965). 


\section{VOLCANIC GREENSTONE}

Overlying the Reshun Formation in Shishi Valley is a sequence of volcanic greenstone that extends northeastward from the southern edge of the map to a point a few miles up the Shishi River, where it pinches out. These rocks in turn are overlain conformably by fossiliferous limestone and phyllite of Cretaceous age.

The volcanic greenstone consists of mafic porphyritic lava flows and some tuffs and volcanic conglomerate, all metamorphosed to low-grade greenstone. Some calcareous red phyllite is interbedded with the volcanic flows. The flows are olivine basalt containing phenocrysts of plagioclase, augite, and olivine in a finegrained groundmass. Chalcopyrite is an accessory mineral in some flows.

\section{LIMESTONE AND PHYLLITE}

A belt of limestone and phyllite overlies the volcanic greenstone. This belt of rocks extends northeastward from the southern edge of the mapped area and follows Shishi Valley. North of Gurin village the volcanic greenstone pinches out and the limestone and phyllite unit is in contact with the Reshun Formation. The unit consists mainly of dark-gray, thin-bedded limestone interbedded with black phyllite and black calcareous shale. Orbitolina found in calcareous limestone beds on the east bank of the Chitral River 2 miles $(3.2 \mathrm{~km})$ south of Drosh indicate a Cretaceous age for this unit. Orbitolina specimens were first found at this locality by Hayden (1915, p. 279). Collections during the present investigation were identified by R. C. Douglass, U. S. Geological Survey.

\section{GREENSCHIST}

A continuous belt of greenschist, extending diagonally northeastward across the mapped area (pl. l), overlies by a gradational contact the middle outcrop belt of the Reshun Formation and is in gradational contact with the overlying Chitral Slate.

The greenschist is pale-green, fine-grained, thinly laminated schist containing varying amounts of sodic plagioclase, actinolite, epidote, chlorite, and quartz. It probably represents chloritic and somewhat calcareous sedimentary beds and some volcanic tuffs. A few nonlaminated layers containing relict feldspar phenocrysts and accessory chalcopyrite indicate the presence of some volcanic flows. Other rock types seen occasionally in the greenstone unit include quartzose sandstone, marble, calcareous phyllite, and slate. Although different petrographically, the greenschist may be equivalent to the volcanic greenstone unit.

\section{CHITRAL SLATE}

The Chitral Slate was first referred to by Hayden (1915, p. 282) as the "slate series of Chitral." A short time later Tipper (in Fermor, 1922, p. 56) called these rocks the "Chitral Slate series." Chitral refers to the village of Chitral. In this report, this rock unit is called the Chitral Slate.

The Chitral Slate forms a northeast-trending belt 3 to 9 miles $(4.8-14.5 \mathrm{~km})$ wide following roughly the course of the Chitral and Mastuj Rivers. As far north as the Lutkho River, the western margin of the slate is in gradational contact with the marble of the Reshun Formation; north of the Lutkho River, the contact is faulted. The eastern margin of the Chitral Slate is gradational with the greenschist unit.

The Chitral Slate consists mainly of fine-grained black slate and thinly laminated phyllite. The slate is made up of alternating laminae of clay- and silt-sized material and tends to break into flat slabs along cleavage planes. Layers of thick-bedded, fine- to medium-grained graywacke which contains black phyllite partings are also present. The thinly laminated phyllite is green or black and consists of micaceous minerals arranged in paper-thin laminae. In some places, the phyllite contains thin beds of marble in which the component laminae are streaked out by internal deformation.

The age of the Chitral Slate has always been considered to be Paleozoic (Tipper, in Fermor, 1922, p. 56; Stauffer, written commun., 1965), on the basis of a single fossil locality in Chitral Gol. Tipper (in Fermor, 1922 , p. 56) states that it contains "a spirifer, a small Dielasma, and two as yet undetermined corals." Secondary evidence supporting the Paleozoic age of the Chitral Slate is the fact that the adjacent Cretaceous rocks in the Reshun area are faulted against the Chitral Slate.

However, the following information obtained during the present field study indicates that the Chitral Slate is Cretaceous in age:

1. Between Kafiristan and a point near the Lutkho River, the western edge of the Chitral Slate is in gradational contact with the underlying marble of the Reshun Formation, which is Cretaceous in age.

2. Near the point where Birir Gol joins the Chitral River, the eastern edge of the Chitral Slate is in gradational contact with the greenschist unit. Also, at this place, crossbedding in quartzose sandstone (quartzite) indicates that the Chitral Slate overlies the greenschist.

3. Along the Mastuj River opposite Turen Kuzhu village, the contact zone between the Chitral Slate and the greenschist consists of interbedded marble, calcareous phyllite, and slate. Although the contact itself was not exposed, this lithology indicates a probable gradational contact. 
4. The regional geologic picture becomes clear and simple if the Chitral Slate is Cretaceous in age (pl. 2). If true, the Chitral Slate forms the trough of a long, narrow syncline overturned toward the east and southeast, and flanked by progressively older rocks on both limbs. On the contrary, if the Chitral Slate is assumed to be of Paleozoic age, an improbable regional geologic structure is required. On the western and northwestern side of the Chitral Slate, the regional geologic map would show a continuous thin band of Cretaceous rocks (Reshun Formation) more than 100 miles $(161 \mathrm{~km})$ long, bounded on both sides by Paleozoic rocks.

Although not specifically proved, the Chitral Slate is considered to be of Cretaceous age on the basis of these considerations.

\section{QUATERNARY DEPOSITS}

Quaternary deposits consist of alluvial sand, gravel, and boulders in the streambeds; alluvial terraces above the streambeds; scree, talus, and landslide debris on the slopes; and upland alluvium, including boulder fields in the high basins and upper reaches of the main creeks. Only the larger deposits of alluvium and the terrace deposits along the Chitral River are shown on plate 1. In the Hot Springs area, river alluvium and terrace deposits have been combined. The only significant deposits of river alluvium are along the Chitral River, the Shishi River, and in the Hot Springs area. Narrow, discontinuous strips of alluvium exist along other major rivers and major creeks, but they are too small to show on the geologic map at the scale used.

Terraces, which stand as high as 900 to $1,400 \mathrm{ft}$ $(274-427 \mathrm{~m})$ above the present river level, consist of poorly bedded stream deposits of clay, silt, sand, gravel, and boulders. Layers of silt and sand commonly are crossbedded, and some black clay layers are convolute. Boulders in the boulder beds consist of granite, granite gneiss, amphibolite, marble, quartzite, and slate.

Scree, talus, and landslide debris are widespread throughout the mapped area, particularly along the main rivers, where they extend upward at angles ranging from $30^{\circ}$ to $37^{\circ}$ for as much as $2,000 \mathrm{ft}(610 \mathrm{~m})$ above river level. These deposits cover the bedrock over long stretches of the streams.

Above an altitude of $11,000 \mathrm{ft}(3,353 \mathrm{~m})$, numerous small upland basins are situated at the foot of the higher ridges and peaks. They characteristically are filled with avalanche debris and angular boulders resulting from frost heaving, snowslides, and other manifestations of alpine weathering. These basins are dotted with bogs and swamps as a result of snowmelt and generally poor drainage; above $14,000 \mathrm{ft}(4,267 \mathrm{~m})$, glacial cirques have formed. The permanent snowline is at an altitude of about $15,000 \mathrm{ft}(4,572 \mathrm{~m})$ and small permanent snow- fields exist on the north- and northwest-facing slopes down to $14,000 \mathrm{ft}(4,267 \mathrm{~m})$.

\section{GRANITE}

Five large bodies of granite are present in the mapped area. Informal names have been applied for convenience as follows: the granite at Hot Springs, located near the Hot Springs in the northwestern corner of the map; the granite of Kafiristan in the western part of the area; the granite of Tirich Mir in the northern part of the area; the granite of Koghozi, 4 miles $(6.4 \mathrm{~km})$ east of Koghozi; and the granite in Shishi Valley located along the upper eastern slopes of Shishi Valley in the southeastern part of the map area. The term granite is used here as a general field name, not in the strict petrologic sense. Identification of these rocks is based upon handspecimen study at the outcrop; microscope studies of thin sections of the granites were not made.

The granite of Hot Springs is white, medium-grained, nonporphyritic, biotite-muscovite granite. It is weakly foliated parallel to the foliation of the adjacent country rock. The contact with the country rock, seen in many places, is intrusive and knife-edge sharp.

The granite of Tirich Mir forms an elongate, northeast-trending belt that pinches out in a southwestward direction. Along the Lutkho River it is only $200 \mathrm{ft}(61 \mathrm{~m})$ thick, well foliated, and in sharp intrusive contact with the adjacent schist. In Arkari Gol, the exact contacts were not accessible. Along this section, the granite is porphyritic, well foliated, and in a few places shows a swirly structure as brought out by the feldspar phenocrysts.

Little information is available on the granite of Kafiristan. Seen only in Rumbur Gol, it is mediumgrained, porphyritic, and its eastern contact with the adjacent schist is a shear zone. Its southern limit is roughly indicated by the fact that no granite is present in Bumboret Valley. The northern limits of this granite body are not known.

The granite of Koghozi forms a northeast-trending linear belt along the high ridgeline between the Chitral and Shishi Rivers. Southwest of Drosh, this granite pinches out. The western contact is faulted against the Reshun Formation. The eastern contact, well exposed along the Chitral River and in Jingeret Gol, is gradational; that is, as the granite is approached, the country rock, because of an increase in feldspar augen and in quartz-feldspar layers, becomes more and more like granite. The granite of Koghozi is gray, fine- to mediumgrained, foliated, nonporphyritic granite which is characterized especially by its generally cataclastic texture.

The granite in Shishi Valley is along the upper slopes of the eastern side of the Valley. Several attempts to 
traverse part of the actual granite were unsuccessful because of waterfalls and other barriers along the creeks. Although the actual contact was never reached, a progressive change to higher-grade metamorphic rocks toward the granite was noted, starting with lowgrade greenschist and progressing to amphibolite containing scattered layers of granite. Still further upstream, crosscutting and concordant layers of granite become more numerous and in Drosh Gol at a point $4,000 \mathrm{ft}(1,219 \mathrm{~m})$ above Drosh, the outcrops consist of about one third granite and two thirds amphibolite. Presumably, pure granite is further upstream, as indicated by boulders of medium-grained nonporphyritic granite in the streambed.

\section{STRUCTURE}

The structure of the area shown on plate 1 is subdivided into several belts by four north- and northeasttrending reverse faults, which are named the Reshun, the Ayun, the Naz Bar, and the Shishi faults. These faults, which in places are thrusts, separate belts of differing age groups, and they provide one of the main keys to the structural interpretation of the area. Two additional faults which are similar in habit to the main faults are the Pasti and the Krinj faults-both in the Partsan area. On the basis of supplementary information available from outside the mapped area, the four main faults, and the outcrop belts they enclose, are extended far to the northeast, as shown on plate 2 . The structural relations interpreted in this report are shown in the cross sections of plate 1 , as well as on the geologic maps.

\section{RESHUN FAULT}

The Reshun fault, named after the village of Reshun (pl. 2), separates the Devonian to Jurassic rocks on the west and northwest from the Reshun Formation and other Cretaceous rocks on the east and southeast. This fault is well documented in most of the map area of plate 1 and by Stauffer in the Reshun area (Stauffer, written commun., 1965). It is inferred to continue northeastward to the vicinity of Baroghil Pass, as shown on plate 2. Between Reshun and Partsan, it is a thrust fault dipping northward at about $30^{\circ}$. At Partsan, the Reshun fault turns northwest for 4 miles $(6.4 \mathrm{~km})$, then swings southwest and south where it changes to a reverse fault. It has been traced southward past Shoghot on the Lutkho River as far as Birir Gol in Kafiristan, where it disappears. At Shoghot, the fault dips $80^{\circ} \mathrm{W}$. In A wireth Gol 1 mile $(1.6 \mathrm{~km})$ south of Shoghot, the fault forms a horsetail structure $1,000 \mathrm{ft}(305 \mathrm{~m})$ wide and 3 miles $(3.2 \mathrm{~km})$ long, containing several individual fault slices. In this area and southward to Kafiristan, the fault $\operatorname{dips} 60^{\circ} \mathrm{W}$. to vertical.

\section{AYUN FAULT}

The Ayun fault extends northeastward from Drosh past Koghozi and separates the Cretaceous rocks of the Chitral syncline on the west from granite and Devonian to Jurassic rocks on the east. This fault has been extended northeastward to join the Holojut fault of Matsushita and Huzita $(1965$, p. 10, 11, 21). At Darkot, the Ayun fault separates the large granite mass on the north from the Darkot Group (Devonian to Jurassic rocks of pl. 2) on the south (Matshushita and Huzita, 1965, p. 21).

The Ayun fault was clearly verified only at one place: namely, on the left (southeast) bank of the Chitral River 1 mile $(1.6 \mathrm{~km})$ southeast of Gahirat, where it forms a narrow shear zone dipping $45^{\circ} \mathrm{W}$. In Golen Gol, 2 miles $(3.2 \mathrm{~km})$ east of Koghozi, a well-defined shear zone is not present. The only evidence for faulting is several cataclastic layers found in the granite at and near the contact with the Reshun Formation. The contact at this place appears to be more of the nature of an intrusive contact.

Similarly, in Jingeret Gol, 2 miles $(3.2 \mathrm{~km})$ southwest of Drosh, thinly banded cataclastic layers in the Koghozi granite are the only indication of faulting. As marked shearing is absent in two of the three places observed, it is possible that the Ayun fault may not be as important a fault as is implied on the geologic maps of plates 1 and 2 . Possibly the junction between the Koghozi granite and the Reshun Formation is basically an intrusive contact, largely or partly obscured by shearing. Further informa: tion is needed.

\section{NAZ BAR FAULT}

The Naz Bar fault, so named by Matsushita and Huzita (1965, p. 76, 77, 78, 80), after Naz Bar (creek) at Yasin, (pl. 2) separates the granite and Devonian to Jurassic rocks on the northwest from the narrow belt of Cretaceous rocks on the southeast. It extends from Drosh in a northeasterly direction and continues along the west side of the Shishi River to the edge of the area of plate 1. It is well exposed at Jingeret Gol, 3 miles $(4.8 \mathrm{~km})$ south of Drosh; on the west bank of the Chitral River, 1 mile $(1.6 \mathrm{~km})$ north of Drosh; at both abutments of the bridge across the Shishi River; at Tar on the Shishi River 7 miles $(11 \mathrm{~km})$ from Drosh; and in the vicinity of Kalas on the Shishi River, 14 miles $(23 \mathrm{~km})$ from Drosh. This fault is inferred to continue northeastward to connect with the Naz Bar fault of Matsushita, which he has traced from the south of Mastuj to the north of Yasin, a distance of about 50 miles $(80 \mathrm{~km})(\mathrm{pl} .2)$. As in the area of plate 1 of this report, Matsushita (Matsushita and Huzita, 1965, p. 85) found that the Naz Bar fault separates the Darkot Group (Devonian to Jurassic rocks of this report) on the north 
from the Yasin Group and Green Series (Cretaceous rocks of this report) on the south. In the Drosh-Shishi Valley area, the fault dips steeply to the west and is marked by a shear zone 80 to $200 \mathrm{ft}$ (24-61 m) wide, made up mainly of sheared serpentine and smaller amounts of brecciated greenstone, sheared and altered talcose schist, black brecciated limestone, and other rock types.

\section{SHISHI FAULT}

The Shishi fault lies east of the Naz Bar fault and separates Cretaceous rocks on the west from Devonian to Jurassic rocks on the east. It extends northeastward from east of Drosh to the east edge of the mapped area (pl. 1). The Shishi fault is inferred to join the Naz Bar fault a few miles northeast of the mapped area, and to extend southwestward beyond the mapped area of plate 1 as far as the Pakistan-Afghan border, as shown on plate 2. The fault was observed in Drosh Gol, Kaldam Gol, Purit Gol, and at the eastern edge of the mapped area. The fault is marked by a shear zone that dips $75^{\circ}$ W. to vertical. In Drosh Gol, the fault zone, which is about $80 \mathrm{ft}(24 \mathrm{~m})$ wide, consists of sheared serpentine $(30 \mathrm{ft})(9 \mathrm{~m})$ and brown-weathering silica-carbonate breccia $(50 \mathrm{ft})(15 \mathrm{~m})$. In Purit Gol and Gawuch Gol, only narrow shear zones, 3 to $10 \mathrm{ft}(0.9-3 \mathrm{~m})$ wide, are evident.

\section{AREA WEST AND NORTH OF THE RESHUN FAULT}

In the large area of Devonian to Jurassic rocks west of the Reshun fault, the structural trend swings from north in Kafiristan to northeast in the northern part of the map area. In the Kafiristan-Hot Springs-Shoghot area, the Devonian to Jurassic rocks are metamorphosed and little is known about the larger fold structures. Tight isoclinal folding and penetrative deformation are universal in the rocks of this area. The foliation, which trends north and dips steeply west, provides the overall structural grain. Two prominent marker beds-the marble unit and the amphibolite unit-also help to delineate the overall structural trend. Fold-axis lineation plunges both north and south at low to moderate angles. Large parts of this area are occupied by granite, which also is foliated.

Beginning at Partsan, however, the degree of metamorphism decreases markedly, and essentially sedimentary beds containing fossils outline the northeast-trending structure of this area. Between Partsan and Pasti, Devonian limestone flanked by the Sarikol Shale outlines a recumbent anticline-called the Partsan anticline-overturned toward the south. From Pasti southwestward to Shoghot on the Lutkho River, the northern outcrop belt of the Sarikol Shale is bounded by the Pasti fault. Rock units of pre-Cretaceous age in the Partsan area abut and partly override Reshun For- 'mation along the Reshun fault. The Reshun Formation in turn has overridden the Chitral Slate along the Krinj fault.

\section{CHITRAL SYNCLINE}

The Chitral syncline is so named for the wide belt of Cretaceous rocks between the Reshun and Ayun faults and occupying the Chitral and Mastuj valleys in the central part of the mapped area. The trend of this structure is slightly east of north, swinging to the northeast at the eastern edge of the map area (pl. 1). The Chitral syncline is inferred to continue for many miles northeastward as defined by the outcrop belts of the Chitral Slate and Reshun Formation on the regional map (pl. 2). In the Kafiristan area, the Chitral syncline is overturned toward the east; in the Partsan area, the north limb of the syncline is overturned toward the south and is partly overridden along the north-dipping Krinj and Reshun faults by Devonian to Jurassic rocks and by the Reshun Formation. The Chitral syncline is isoclinally folded internally so that it is identifiable only in its gross aspect.

Foliation, which is the dominant planar structure at the scale of the outcrop, dips generally west at steep angles. East of the Chitral River, however, the foliation dips east. Microfolds mark the overall trend of the syncline and plunge both north and south at shallow angles. Frequently, both north- and south-plunging microfolds are visible in the same outcrop. A few microfolds plunge down the dip of the foliation, but these are not abundant.

In the Kafiristan area between Lut Gol and Bumboret Gol, the marble of the Reshun Formation shows a peculiar pattern in which, over a distance of 6 miles $(9.6 \mathrm{~km})$, the rock forms two outcrop belts along two parallel ridgelines. The western marble belt extends southward from the precipitous cliffs $2,000 \mathrm{ft}(609 \mathrm{~m})$ above Bumboret Gol, to Lut Gol, where it joins the eastern outcrop belt. The eastern outcrop belt, which extends continuously both north and south for many miles, widens into a large bulge just northwest of Lut Gol.

The peculiar structure probably began as an S-shaped cross fold oriented perpendicular to the regional strike (sometimes referred to as a "flexure along the strike"), and subsequently, the two western parts of the $S$ became highly attenuated. The attenuated cross fold was then refolded into the present south-plunging folds by the dominant stress field of the area. By this interpretation, the western segment of marble forms a closed loop of two limbs of the lengthened nose of a southplunging minor syncline, and the Devonian to Jurassic rocks between the marble belts form a south-plunging minor anticline. Southward, the two limbs of the original S-shaped cross fold have been completely squeezed together to form a single outcrop belt. 
The northeastern extension of the Chitral syncline beyond Reshun, as shown on plate 2, is based mainly upon unpublished reconnaissance maps of Tipper (Tipper, G.H., Geological Survey of India, unpub. data, 1926), who shows a continuous belt of Chitral Slate from south of Chitral to Brep, 12 miles $(19 \mathrm{~km})$ northeast of Mastuj. At Brep, the slate belt splits into two narrow belts around an elongate body of granite, the northern belt continuing along the Yarkhun River to Baroghil Pass. Tipper shows no faults or other structural details, and the extension of the northern faulted boundary of the Chitral syncline is mainly speculative.

\section{KOGHOZI ANTICLINE}

The Koghozi anticline is the name given to the probable anticlinal structure lying between the Ayun and $\mathrm{Naz}$ Bar faults. An elongate body of granite, the granite of Koghozi occupies the core and is flanked on both sides by Devonian to Jurassic rocks and Cretaceous rocks. This anticlinal structure is inferred only on the basis of the apparent ascending stratigraphic sequence away from the inferred anticlinal axis and on the hypothesis that the granite bodies in this area appear to represent elongate domes. Northeast of the area of plate 1, the anticlinal structure and the faulted boundaries enclosing it are extended to include the granite and the Darkot Group of Ivanac (Ivanoc and others, 1956) and Matsushita (Matsushita and Huzita, 1965). The large elongate body of granite lying between Mastuj and Darkot is considered to represent the core of the anticlinal structure of that area.

Foliation, the dominant planar structure within the Koghozi anticline, follows the northeast structural trend of the map area, and dips steeply west from $60^{\circ}$ to $90^{\circ}$. Small-scale folds on foliation planes plunge at shallow angles both northeast and southwest.

\section{STRUCTURE OF CRETACEOUS ROCKS AT DROSH}

At Drosh, and extending northeastward along the Shishi River, a narrow belt of Cretaceous rocks occupies the interval between the Naz Bar and Shishi faults. The belt is 3.5 miles $(5.6 \mathrm{~km})$ wide at Drosh, but narrows northeastward to less than 1 mile $(1.6 \mathrm{~km})$. The rocks within this zone are only slightly metamorphosed, and fossil collections confirm the Cretaceous age of these rocks.

These Cretaceous rocks form a west-dipping sequence composed of three rock units: limestone and phyllite at the top; volcanic greenstone in the middle; and the Reshun Formation at the base. Bedding as well as foliation dip steeply to the west. The volcanic greenstone unit pinches out northeastward, but the remaining two units continue to the edge of the mapped area (pl. 1).
Beyond the mapped area, this belt of Cretaceous rocks is inferred to terminate at the point where the Shishi fault joins the Naz Bar fault (pl. 2). This narrow belt between the Naz Bar and Shishi faults is interpreted to represent a downfaulted zone of younger and little-metamorphosed rocks between older and relatively upthrown rocks.

Probable extensions of the Cretaceous rocks at Drosh are found at Yasin and at Chumarkand Pass, 4 miles $(6.4 \mathrm{~km})$ east of Mastuj (pl. 2). The rocks at these localities, which were called the Yasin Group by Ivanac (Ivanoc and others, 1956, p. 10,11), are shown as the Reshun Formation on plate 2. Tipper (in Pascoe, 1924, p. 45) also mentions the presence of the "Reshun conglomerate and shales" at Chumarkand Pass, where " *** it has thickened a good deal and the conglomerate is very massive." Tipper also states that "The Orbitolina limestones (middle Cretaceous) are present together with some trap beds."

\section{STRUCTURE EAST OF SHISHI FAULT}

In the mapped area of plate 1 , little work was done east of the Shishi fault, and therefore, few structural data are available. Foliation in the Devonian to Jurassic metamorphic rocks dips steeply west and trends northeast, parallel to the structural trend of this part of the area.

Northeastward, the Shishi fault merges with the Naz Bar fault which turns to the east and continues across the region (pl. 2). The gross structural trend in the area south of the Naz Bar fault also changes to an eastward direction, but no specific information is given by Ivanac (Ivanac and others, 1956), Matsushita (Matsushita and Huzita, 1965), or Tipper (in Pascoe, 1924, p. 45-46). Although Ivanac placed these rocks in the Triassic, the limestone, phyllite, and volcanic greenstone rocks south of the Naz Bar fault are here considered to be of Cretaceous age, in accordance with the views of Matsushita.

\section{MINERAL DEPOSITS}

The Chitral region has long been known to contain mineral showings of copper, lead, antimony, and arsenic. Antimony in the Krinj-Partsan area has been mined on a small scale since 1939 . The local residents of Chitral town report that some gold washing has been done along the Lutkho and Chitral Rivers.

Some useful nonmetallic mineral deposits also are found in the area. These include marble, limestone, dolomite, pegmatite, and talc. In 1969, pegmatites were being mined on a small scale 10 miles $(16 \mathrm{~km})$ north of Imirdin. Although no special study was made of the 
nonmetallic minerals, a few localities seen in the course of the work are described (see p. 31).

The rugged topography and the remoteness and inaccessibility of the area have generally discouraged the systematic survey of the mineral potential of the region. The only previous field investigations on the minerals of the area are unpublished reports by Sondhi (1942) and Nath (1944) on the antimony resources of Chitral State; a report by Rahman (1949) on the Drosh area; and a reconnaissance survey by S. T. Ali (1949). S. T. Ali traveled extensively, mainly on foot, throughout Chitral State, and his unpublished report constitutes the basic reference for the mineral deposits and showings of Chitral State as a whole. Several summary reports also have been compiled on the minerals of Chitral State, the latest and most comprehensive of which is that by M. G. White (1965) on copper, lead, zinc, antimony, and arsenic in Pakistan. Others include Heron (1950) and Coulson (1940).

In the area of the present investigation, 37 localities containing copper, lead, and antimony in various combinations were visited, and one small talc locality. An index map of the mineral localities is shown in figure 3 . All the localities on figure 3 have been visited except the copper-lead showing at Imirdin and the mica-beryl deposits north of Imirdin.

In order to obtain basic information on the metals content of the area, samples were collected of altered and mineralized rocks. These samples have been analyzed in the laboratories of the U. S. Geological Survey. Locations of the rock and ore samples analyzed are shown in figure 4. Results of the spectrographic analyses are listed in table 1 , and the partial chemical analyses in table 2 .

The rock samples are mainly from the mineral localities shown in figure 3 , but also include several samples of altered rocks and a few bleached soil samples that are not directly connected with mineral showings. Some of the samples consist of altered or mineralized talus boulders rather than bedrock, as the bedrock was not always accessible. In general, the aim of the sampling was to obtain the most high-grade specimen available, with the idea that if the high-grade specimen failed to show encouraging results, a laboriously obtained random sample would not. Where conditions warranted, however, area-chip samples and channel samples were taken.

The analyses completed thus far reveal the presence of several metals that have not been previously reported. These include gold, silver, copper, and tin associated with the lead ore of the Awireth Gol locality, and traces of lead, copper, gold, silver, and vanadium associated with the antimony ore of the Krinj-mines. It appears that the mines and mineral showings of this region have not previously been systematically analyzed for their associated metals.

Most of the metallic mineral localities are concentrated in the Shoghot-Krinj-Partsan area, the Koghozi area, and in the Drosh-Shishi Valley area. However, copper in small quantities is widely distributed throughout the mapped area, and is found in almost every rock type. The metallic mineral localities can be divided into the following three main groupings: (1) veins containing antimony, lead, and copper with several associated metals including gold, silver and tin; (2) copper in mafic rocks and greenschist; and (3) miscellaneous mineral showings mainly containing copper.

\section{VEINS CONTAINING ANTIMONY, LEAD, AND COPPER}

\section{AWIRETH GOL LOCALITY}

The Awireth Gol locality is a vein of lead-antimony ore located in Awireth Gol 3 miles $(4.8 \mathrm{~km})$ southwest of Shoghot on the steep, west-facing slope of Awireth valley at an altitude of $9,282 \mathrm{ft}(2,829 \mathrm{~m})$. It is about $3,400 \mathrm{ft}(1,036 \mathrm{~m})$ above the river level at Shoghot and is accessible by a fairly good footpath up Awireth Gol to a point opposite the prospect, then by a steep climb of $1,200 \mathrm{ft}(366 \mathrm{~m})$ directly up the slope. Although the locality is small, the material there is the highest grade of any seen in the Chitral area.

The vein has been opened along the strike by a shallow irregular excavation $40 \mathrm{ft}(12 \mathrm{~m})$ long. At the south end of the excavation, a small tunnel has been dug along the thickest part of the vein for an additional $10 \mathrm{ft}(3 \mathrm{~m})$. There has been no production, but in 1968 the Chitral Mining Company was negotiating a mining agreement with the local Prince. A small stockpile of the ore is stored at the Company's retort plant at Krinj.

The vein is emplaced along a branch fault related to the contact between the marble of the Reshun Formation on the east and black phyllite belonging to the metamorphic rocks of the Kafiristan-Partsan area on the west. This branch fault is the eastern boundary of a large horsetail structure that occupies the area between Awireth Gol and the prospect. The fault at the western edge of the horsetail structure strikes N., $20^{\circ}$ E. and dips $60^{\circ} \mathrm{W}$. The area within the horsetail structure consists of a series of sharp-pointed, tight folds and associated fault slices of dolomite marble and black phyllite. The branch fault at the prospect is a breccia zone 50 to $60 \mathrm{ft}\left(15-18 \mathrm{~m}\right.$ ) wide striking N., $40^{\circ} \mathrm{E}$. and dipping $70^{\circ} \mathrm{E}$. The marble on the east side of the fault forms an inaccessible, nearly sheer wall rising upward to the top of the ridge. The breccia zone contains the leadantimony vein plus numerous quartz veins and stringers disposed along local shear and gouge zones. In a short tunnel at the southern end of the workings, the lead- 


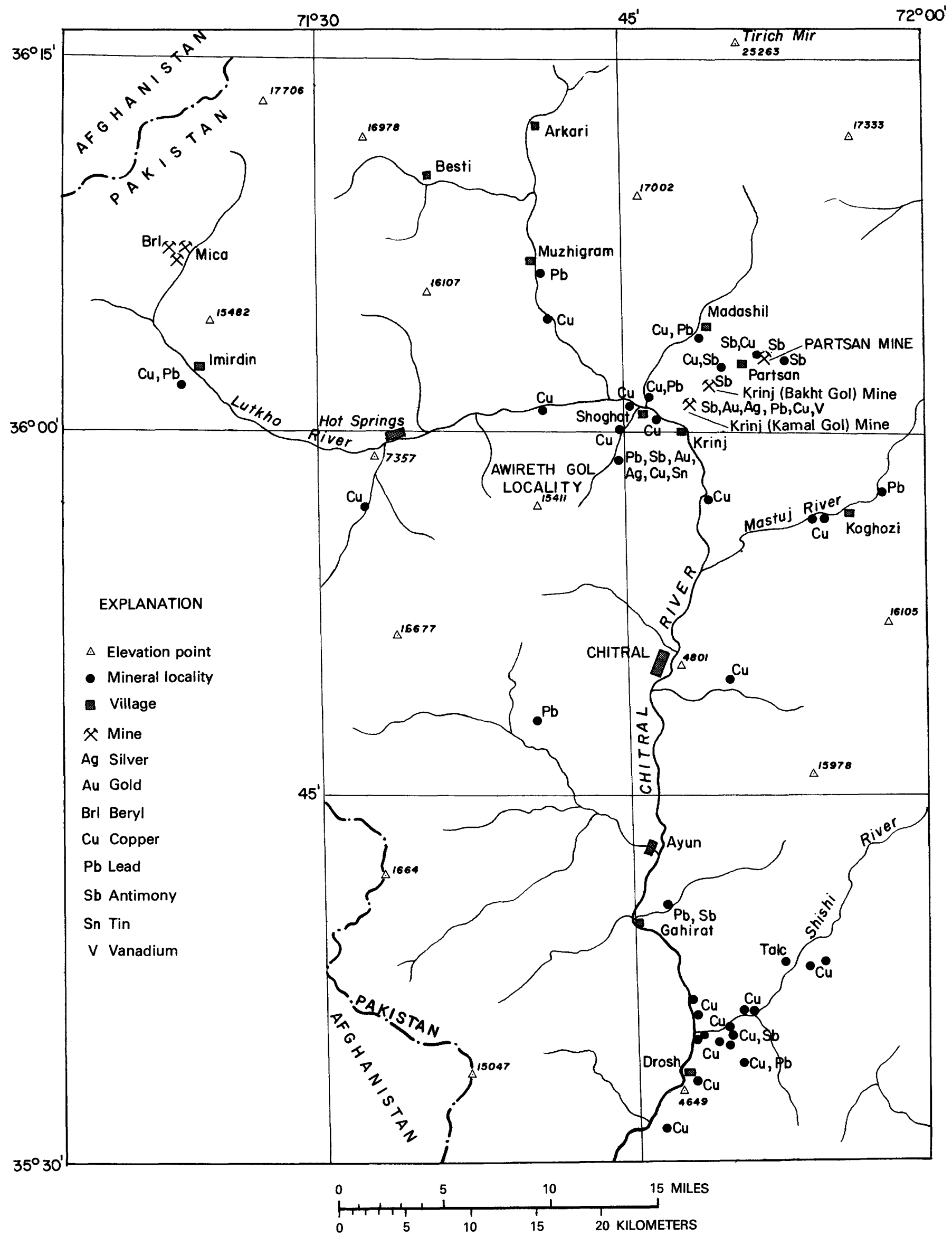

Figure 3.-Mineral localities in the Chitral-Partsan area, northern Pakistan. 


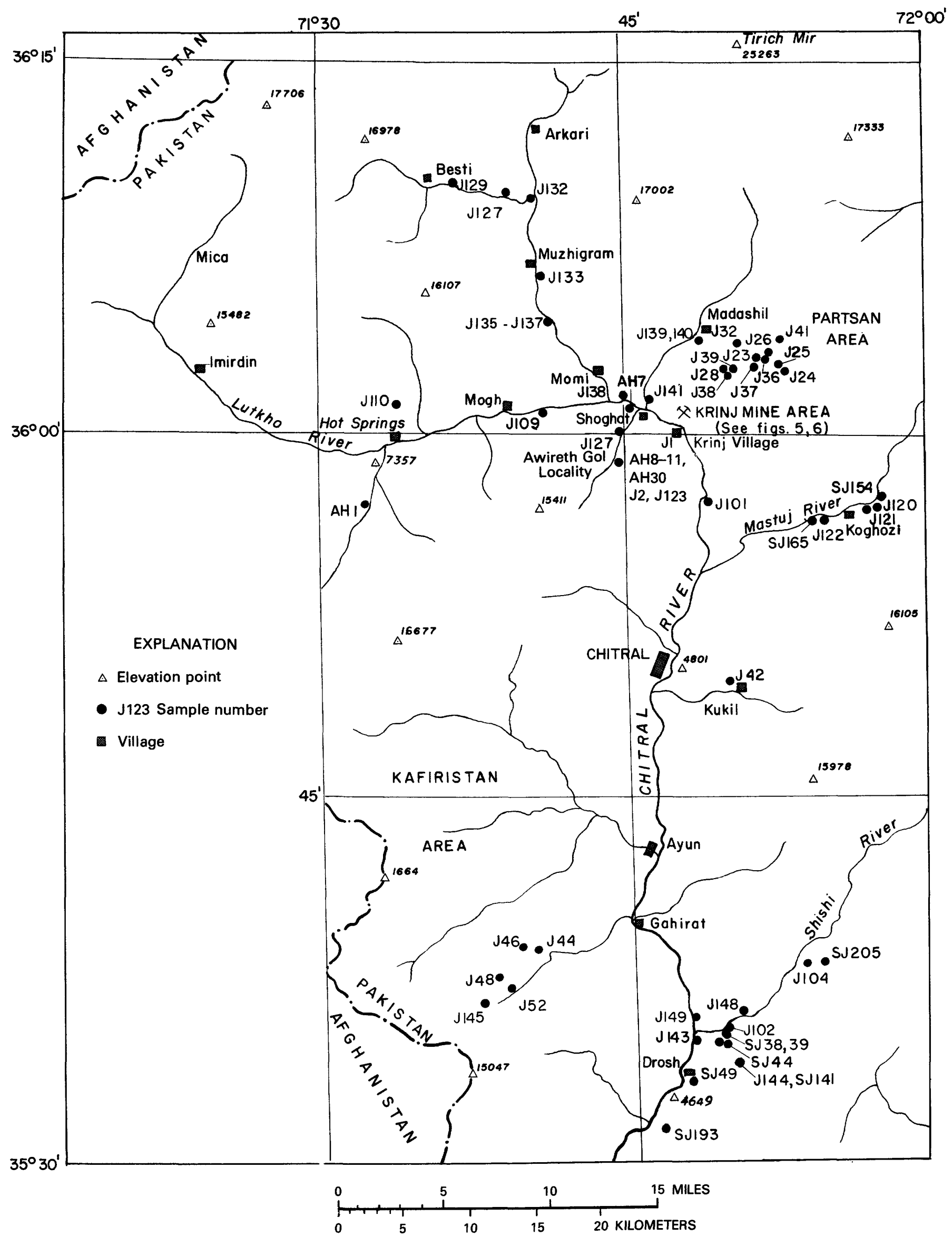

Figure 4.-Map showing locations of analyzed rock and ore samples, Chitral-Partsan area, northern Pakistan. 
antimony vein follows a local subsidiary shear striking $\mathrm{N} ., 30^{\circ} \mathrm{E}$. and dipping $30^{\circ} \mathrm{SE}$., and is somewhat curving and irregular. At the north end of the tunnel, the vein consists of solid lead-antimony ore $4 \mathrm{ft}(1.2 \mathrm{~m})$ thick, tapering to $2 \mathrm{ft}(0.6 \mathrm{~m})$ at the south end of the tunnel 10 $\mathrm{ft}(3 \mathrm{~m})$ distant. About $20 \mathrm{ft}(6 \mathrm{~m})$ updip, the vein pinches out, and the ground surface above the tunnel is marked only by a narrow shear and gouge zone a foot thick. To the northeast, the vein pinches and swells, and $40 \mathrm{ft}(12$ m) to the north, at the northern end of the excavation, the vein, which is still $4 \mathrm{ft}(1.2 \mathrm{~m})$ thick, consists mainly of quartz having only scattered stringers of antimonylead ore, with one streak of solid ore 6 inches $(0.15 \mathrm{~m})$ thick. At both ends of the excavation, the continuation of the vein is covered by talus.

The ore consists mainly of black, fine-grained leadantimony sulfides, accessory chalcopyrite and pyrite, and small amounts of quartz and dolomite gangue. In places, the ore is stained by malachite (green) and secondary arsenic (yellow). The lead-antimony sulfides are too fine grained to be identified in a hand specimen.

Samples taken at intervals across the $4 \mathrm{ft}(1.2 \mathrm{~m})$ width of the vein all contain large amounts of silver and gold as well as smaller amounts of tin, vanadium, and other metals. Spectrographic analyses of five samples (table 1) show a range of 500-2,000 ppm (parts per million) silver and 15-200 ppm gold (table 1). The average of the five samples is $980 \mathrm{ppm}(32.7 \mathrm{oz})$ silver and $77 \mathrm{ppm}(2.6 \mathrm{oz})$ gold. Although lead and antimony constitute the bulk of the ore, the value of these and other metals is overshadowed by the silver and gold content.

The reserves can only be roughly approximated because of the irregularities of the vein. The visible part of the vein is roughly lens shaped, tapering at both ends as well as up the dip. The exposed length of the vein is 30 $\mathrm{ft}(9 \mathrm{~m})$ and the visible distance along the dip direction is $20 \mathrm{ft}(6 \mathrm{~m})$. If we assume that the average thickness is 2 $\mathrm{ft}(0.6 \mathrm{~m})$, and that the vein extends an additional $10 \mathrm{ft}$ $\mathrm{m}^{3}(3 \mathrm{~m})$ downdip, the volume of indicated ore is $30 \times 30 \times 2 \mathrm{ft}(9 \times 9 \times 0.6 \mathrm{~m})=1,800 \mathrm{cu}$. ft $\left(48.6 \mathrm{~m}^{3}\right)$. One ton of ore, having specific gravity of 6 , occupies $5.6 \mathrm{cu}$. $\mathrm{ft},\left(0.16 \mathrm{~m}^{3}\right)$, and on this basis, the reserves are 320 tons (290 metric tons).

\section{KRINJ MINE AREA}

The Krinj mine area is 2 miles northeast of Krinj in the hills north of the Lutkho River. It consists of a series of underground workings distributed for 1.5 miles $(2.4 \mathrm{~km})$ along the base of a limestone escarpment. There are three separate mines: the Angarum mine at the southwestern end of the mine area, the Kamal Gol mine in the middle area, and the Bakht Gol mine at the northeastern end of the mine area. A tape-compass survey of the Kamal Gol mine area is shown in figure 5. The Angarum and Bakht Gol mines have been closed for many years and all production comes from the Kamal Gol mine. No information is available on the Angarum mine and, therefore, it is not discussed in this report. Its former location has been covered over by landslides and rockfalls.

\section{HISTORY AND PRODUCTION}

According to unpublished data by V. P. Sondhi (1942), Mukti Nath (1944) and S. T. Ali (1949), the antimony ore at Krinj was first discovered in 1935. Production began in 1939 under a mining lease held by the Pardkh Verani Mining Syndicate of Bombay. The mining and transport of the ore was done by the Chitral Trading and 'Transport Co., Chitral, under a contract with the lessees. The ore was transported 39 miles $(63 \mathrm{~km})$ by truck to Drosh at the foot of Lawari Pass, then 36 miles $(58 \mathrm{~km})$ by mules over the pass to Dir. At Dir, the ore was transferred to trucks once again and moved another 89 miles $(143 \mathrm{~km})$ to the railhead at Durgai. From Durgai, the ore was carried by train to Bombay where it was smelted into antimony metal by the Star Metal Co., Bombay.

After 3 years of unprofitable operation, the mining syndicate took over the management of the mine themselves and furnished their own staff and trucks for transporting the ore. During the war years when antimony was in great demand, the mine must have been quite profitable, although actual figures are not available. In 1944, when Mukti Nath, Geological Survey of India, visited the mines, a sizable community existed on a rocky prominence at the minesite, and the staff included 162 miners, 7 crew chiefs, 2 blacksmiths, one mine foreman, and one resident engineer (Nath, 1944). Wages for the miners were Rs. $1.00 /$ day (about $\$ 0.25 /$ day). At that time the mine consisted of two adits and seven working faces, totaling about $500 \mathrm{ft}(152 \mathrm{~m})$ of underground workings. These workings are somewhat below and southwest of the present workings, and have been caved for several years.

Production continued under the direction of the mining syndicate until 1947, when India and Pakistan became separate States. In 1954, the mining lease was taken over by Pakistan Industries, Ltd., Karachi, who organized a subsidiary company, the Chitral Mining Co., to run the mines. Production was resumed in 1956 and was continuing in 1969.

Before 1947, the raw antimony ore was shipped to Bombay for processing into antimony metal; but when production was resumed in 1956, a retort for making antimony oxide was installed at Krinj village. Since 1957, antimony oxide has been produced at Krinj and shipped to Karachi for direct export, mainly to the United Kingdom and the United States. 
TABLE 2. - Partial chemical analyses of samples from the Chitral-Partsan area

[Elements reported in parts per million except where percent is indicated. For sample locations see plate 2 and figures 2,3 and 4 . Analysts C. L. Burton and F. W. Brown]

\begin{tabular}{|c|c|c|c|c|c|c|c|c|c|}
\hline $\begin{array}{c}\text { Sample } \\
\text { No. }\end{array}$ & $\mathrm{Ag}$ & As & $\mathrm{Au}$ & $\mathrm{Cu}$ & $\mathrm{Hg}$ & $\mathrm{Pb}$ & $\mathrm{Sb}$ & $\mathrm{Sn}$ & V \\
\hline \multicolumn{10}{|c|}{ AWIRETH GOL LOCALITY } \\
\hline $\begin{array}{l}\text { J2 } \\
\text { AH8 } \\
\text { AH9 } \\
\text { AH10 } \\
\text { AH11 }\end{array}$ & $\begin{array}{r}580 \\
540 \\
390 \\
660 \\
1,200\end{array}$ & $\begin{array}{l}1.4 \% \\
1.3 \% \\
1.7 \% \\
0.80 \%\end{array}$ & $\begin{array}{l}43 \\
22 \\
59 \\
21 \\
38\end{array}$ & $\begin{array}{l}.0340 \% \\
.0180 \% \\
.0310 \% \\
.0790 \%\end{array}$ & $\begin{array}{l}<1 \\
<1 \\
<1 \\
<1\end{array}$ & $\begin{array}{l}51.2 \% \\
45.2 \% \\
56.6 \% \\
50.5 \%\end{array}$ & $\begin{array}{l}12.8 \% \\
15.6 \% \\
14.7 \% \\
17.0 \%\end{array}$ & $\begin{array}{l}0.1 \% \\
0.1 \% \\
0.1 \% \\
0.1 \%\end{array}$ & $\begin{array}{c}10 \\
9.1 \\
9.1 \\
8.4\end{array}$ \\
\hline $\begin{array}{l}\text { J123 } \\
\text { AH30 }\end{array}$ & 8 & & .35 & & & & & & \\
\hline
\end{tabular}

KRINJ MINE AREA

lower adit (adit 2A)

\begin{tabular}{|c|c|c|c|c|c|c|c|c|c|}
\hline $\begin{array}{l}\text { J55 } \\
\text { J56 } \\
\text { J57 } \\
\text { J58 } \\
\text { J59 }\end{array}$ & $\begin{array}{l}<2 \\
<2 \\
<2 \\
<2 \\
<2\end{array}$ & & $\begin{array}{c}2.9 \\
.06 \\
.06 \\
.07 \\
<.05\end{array}$ & & & & & & \\
\hline $\begin{array}{l}\text { J60 } \\
\text { J61 } \\
\text { J62 } \\
\text { J63 } \\
\text { J64 }\end{array}$ & $\begin{array}{r}<2 \\
<2 \\
<2 \\
5 \\
<2\end{array}$ & & $\begin{array}{l}<.05 \\
.14 \\
.1 \\
.07 \\
.2\end{array}$ & & & & & & \\
\hline $\begin{array}{l}\text { J65 } \\
\text { J66 } \\
\text { J67 } \\
\text { J68 } \\
\text { J69a }\end{array}$ & $\begin{array}{c}<2 \\
<10 \\
<10 \\
4.2 \\
<10\end{array}$ & $\begin{array}{l}.023 \% \\
.03 \% \\
.074 \%\end{array}$ & $\begin{aligned} & .4 \\
& .2 \\
&<.05 \\
& .4 \\
& .4\end{aligned}$ & $\begin{array}{l}.044 \% \\
.06 \% \\
.030 \%\end{array}$ & $\begin{array}{l}<1 \\
<1 \\
<1\end{array}$ & $\begin{array}{l}.11 \% \\
.084 \% \\
.088 \%\end{array}$ & $\begin{array}{l}29.5 \% \\
29.0 \% \\
37.6 \%\end{array}$ & $\begin{array}{l}<.1 \% \\
<.1 \% \\
<.1 \%\end{array}$ & $\begin{array}{l}35 \\
20 \\
\\
30\end{array}$ \\
\hline $\begin{array}{l}\mathrm{J} 69 \mathrm{~b} \\
\mathrm{~J} 69 \mathrm{~d} \\
\mathrm{~J} 70 \mathrm{a} \\
\mathrm{J} 70 \mathrm{~b}\end{array}$ & $\begin{array}{r}<2 \\
22 \\
<10 \\
<2\end{array}$ & $\begin{array}{l}.71 \% \\
.010 \%\end{array}$ & $\begin{array}{r}.4 \\
.6 \\
.1 \\
4.3\end{array}$ & $\begin{array}{l}.044 \% \\
.033 \%\end{array}$ & $\begin{array}{l}<1 \\
<1\end{array}$ & $\begin{array}{c}<.05 \% \\
.095 \%\end{array}$ & $\begin{array}{l}33.8 \% \\
32.4 \%\end{array}$ & $\begin{array}{l}<.1 \% \\
<.1 \%\end{array}$ & $\begin{array}{l}35 \\
15\end{array}$ \\
\hline \multicolumn{10}{|c|}{ upper adit (adit 1A) } \\
\hline $\begin{array}{l}\text { J71 } \\
\text { J72 } \\
\text { J73 } \\
\text { J74 } \\
\text { J75 }\end{array}$ & $\begin{array}{c}<2 \\
2.7 \\
<2 \\
2.7 \\
<10\end{array}$ & $.001 \%$ & $\begin{array}{l}1.1 \\
.2 \\
.06 \\
.1 \\
.4\end{array}$ & $.011 \%$ & $<1$ & $<.05 \%$ & $2.3 \%$ & $<.1 \%$ & 16 \\
\hline $\begin{array}{l}\text { J76a } \\
\text { J76b } \\
\text { J77 } \\
\text { J78 } \\
\text { J100 }\end{array}$ & $\begin{array}{c}<2 \\
<10 \\
<10 \\
3.4 \\
<10\end{array}$ & $\begin{array}{l}.033 \% \\
.022 \% \\
.81 \%\end{array}$ & $\begin{array}{l}.2 \\
.2 \\
.3 \\
.07 \\
.2\end{array}$ & $\begin{array}{c}<.01 \% \\
.054 \% \\
.017 \%\end{array}$ & $\begin{array}{l}<1 \\
<1 \\
<1\end{array}$ & $\begin{array}{l}<.05 \% \\
<.05 \% \\
<.05 \%\end{array}$ & $\begin{array}{r}37.3 \% \\
17.7 \% \\
.99 \%\end{array}$ & $\begin{array}{l}<.1 \% \\
<.1 \% \\
<.1 \%\end{array}$ & $\begin{array}{l}50 \\
18 \\
50\end{array}$ \\
\hline
\end{tabular}


GEOLOGY AND MINERAL RESOURCES, CHITRAL-PARTSAN AREA, NORTHERN PAKISTAN

TABLE 2.-Partial chemical analyses of samples from the Chitral-Partsan area-Continued

\begin{tabular}{|c|c|c|c|c|c|c|c|c|c|}
\hline $\begin{array}{c}\text { Sample } \\
\text { No. }\end{array}$ & $\mathrm{Ag}$ & As & $\mathrm{Au}$ & $\mathrm{Cu}$ & $\mathrm{Hg}$ & $\mathrm{Pb}$ & $\mathrm{Sb}$ & Sn & $\mathbf{v}$ \\
\hline \multicolumn{10}{|c|}{ OLD WORKINGS AND STOCKPILE (INCLUDES ONE PANNED STREAM SAMPLE) } \\
\hline $\begin{array}{l}\text { J1 } \\
\text { J80 } \\
\text { J81 } \\
\text { J82 } \\
\text { J83 }\end{array}$ & $\begin{aligned} & 2.1 \\
&<10 \\
&<10 \\
&<2\end{aligned}$ & $\begin{array}{l}.0096 \% \\
.051 \%\end{array}$ & $\begin{array}{r}.1 \\
.3 \\
.2 \\
.5 \\
1.4\end{array}$ & $\begin{array}{l}<.01 \% \\
\quad .024 \%\end{array}$ & $\begin{array}{l}<1 \\
<1\end{array}$ & $\begin{array}{r}<.05 \% \\
.090 \%\end{array}$ & $\begin{array}{l}27.0 \% \\
19.9 \%\end{array}$ & $\begin{array}{l}<.1 \% \\
<.1 \%\end{array}$ & $\begin{array}{l}11 \\
50\end{array}$ \\
\hline $\begin{array}{l}\text { J84 } \\
\text { J85 } \\
\text { J86 } \\
\text { J87 } \\
\text { J88 }\end{array}$ & $\begin{array}{c}<10 \\
35 \\
<2 \\
2.4 \\
2.2\end{array}$ & $.011 \%$ & $\begin{array}{l}<.05 \\
1.3 \\
.6 \\
1.7 \\
1\end{array}$ & $.010 \%$ & $<1$ & $<.05 \%$ & $2.0 \%$ & $<.1 \%$ & 20 \\
\hline $\begin{array}{l}\text { J89 } \\
\text { J90 } \\
\text { J91 } \\
\text { J92 } \\
\text { J93 }\end{array}$ & $\begin{array}{c}<10 \\
<2 \\
<2 \\
11 \\
2.2\end{array}$ & $.012 \%$ & $\begin{array}{l}.1 \\
.09 \\
.5 \\
1.1 \\
3.4\end{array}$ & $<.01 \%$ & $<1$ & $<.05 \%$ & $2.0 \%$ & $<.1 \%$ & 25 \\
\hline $\begin{array}{l}\text { J94 } \\
\text { J95 } \\
\text { J96 } \\
\text { J98 } \\
\text { J79 }\end{array}$ & $\begin{array}{l}<10 \\
<10 \\
115 \\
<10 \\
<2\end{array}$ & $\begin{array}{l}.010 \% \\
.066 \% \\
.039 \%\end{array}$ & $\begin{array}{r}.1 \\
.7 \\
1.9 \\
.2\end{array}$ & $\begin{array}{l}.016 \% \\
.016 \% \\
.017 \%\end{array}$ & $\begin{array}{l}<1 \\
<1 \\
<1\end{array}$ & $\begin{array}{l}<.05 \% \\
<.05 \% \\
<.05 \%\end{array}$ & $\begin{array}{r}17.4 \% \\
3.1 \% \\
5.9 \%\end{array}$ & $\begin{array}{l}<.1 \% \\
<.1 \% \\
<.1 \%\end{array}$ & $\begin{array}{l}28 \\
30 \\
\\
50\end{array}$ \\
\hline \multicolumn{10}{|c|}{ PARTSAN AREA } \\
\hline $\begin{array}{l}\mathrm{J} 23 \\
\mathrm{~J} 24 \mathrm{~b} \\
\mathrm{~J} 24 \mathrm{c} \\
\mathrm{J} 25 \\
\mathrm{~J} 26\end{array}$ & $\begin{array}{l}<2 \\
<10 \\
<10 \\
<2 \\
<10\end{array}$ & $\begin{array}{l}.12 \% \\
.050 \% \\
.010 \%\end{array}$ & $\begin{array}{l}<.05 \\
<.05 \\
<.05 \\
<.05 \\
<.05\end{array}$ & $\begin{array}{l}.024 \% \\
.053 \% \\
.034 \%\end{array}$ & $\begin{array}{l}<1 \\
2.2 \\
<1\end{array}$ & $\begin{array}{r}.05 \% \\
<.05 \% \\
.06 \%\end{array}$ & $\begin{array}{l}50.5 \% \\
28.6 \% \\
\\
17.5 \%\end{array}$ & $\begin{array}{l}<.1 \% \\
<.1 \% \\
<.1 \%\end{array}$ & $\begin{array}{l}38 \\
30 \\
\\
30\end{array}$ \\
\hline $\begin{array}{l}\text { J28 } \\
\text { J32 } \\
\text { J36a } \\
\text { J36b } \\
\text { J36c }\end{array}$ & $\begin{array}{l}<2 \\
<2 \\
<2 \\
<2 \\
<2\end{array}$ & & $\begin{array}{l}<.05 \\
<.05 \\
<.05 \\
<.05 \\
<.05\end{array}$ & & & & & & \\
\hline $\begin{array}{l}\text { J36d } \\
\text { J37 } \\
\text { J38 } \\
\text { J38a } \\
\text { J39a }\end{array}$ & $\begin{array}{l}<2 \\
<2 \\
750 \\
<2 \\
<2\end{array}$ & $.28 \%$ & $\begin{array}{c}<.05 \\
<.05 \\
16 \\
.3 \\
<.05\end{array}$ & $2.8 \%$ & $<1$ & $6.7 \%$ & $4.8 \%$ & $<.1 \%$ & 25 \\
\hline $\begin{array}{l}\text { J39b } \\
\text { J29 } \\
\text { J40 } \\
\text { SJ1 } \\
\text { SJ2 }\end{array}$ & $<2$ & & $<.05$ & & & & & & \\
\hline $\begin{array}{l}\text { SJ3 } \\
\text { SJ4 } \\
\text { SJ5 }\end{array}$ & & & & & & & & & \\
\hline
\end{tabular}


TABLE 2.-Partial chemical analyses of samples from the Chitral-Partsan area-Continued

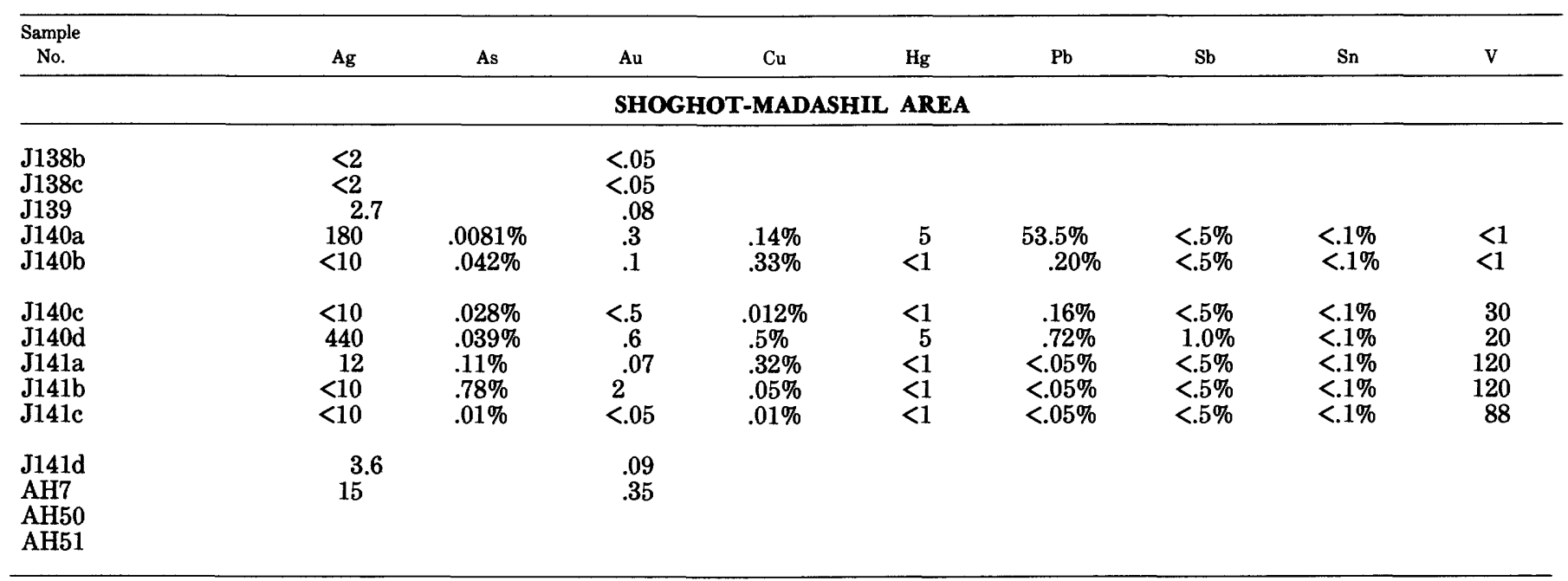

MOGH LOCALITY

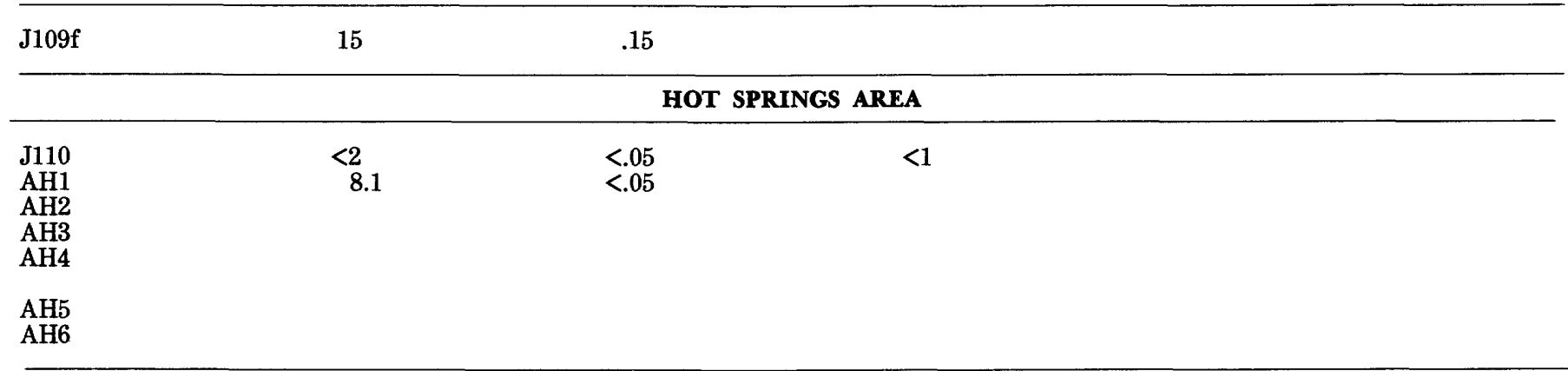

\begin{tabular}{llr}
\hline & & MOMI-BESTI AREA \\
\hline $\mathrm{J} 127$ & $<2$ & $<.05$ \\
$\mathrm{~J} 129$ & 2.2 & $<.05$ \\
$\mathrm{~J} 132 \mathrm{a}$ & $<2$ & $<.05$ \\
$\mathrm{~J} 132 \mathrm{~b}$ & $<2$ & $<.05$ \\
$\mathrm{~J} 133 \mathrm{a}$ & $<2$ & $<.05$ \\
$\mathrm{~J} 133 \mathrm{~b}$ & $<2$ & $<.05$ \\
$\mathrm{~J} 133 \mathrm{c}$ & $<2$ & $<.05$ \\
$\mathrm{~J} 135$ & $<2$ & $<.15$ \\
$\mathrm{~J} 136$ & $<2$ & \\
$\mathrm{~J} 137$ & & \\
$\mathrm{~J} 125$ & & \\
$\mathrm{AH} 37$ & & \\
$\mathrm{AH38}$ & & \\
\hline
\end{tabular}

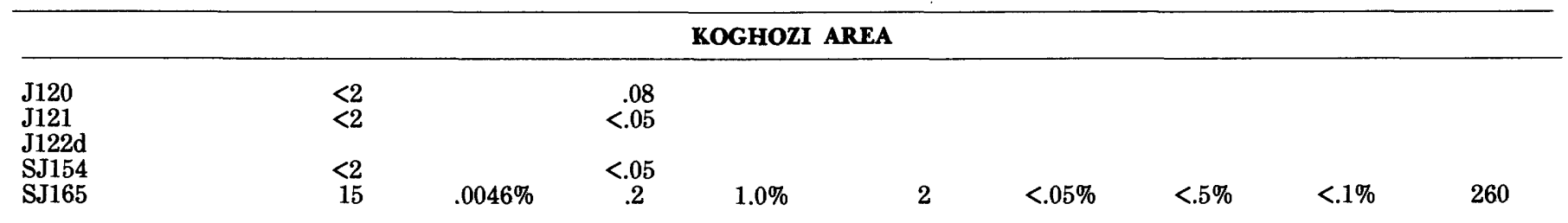


TABLE 2.-Partial chemical analyses of samples from the Chitral-Partsan area-Continued

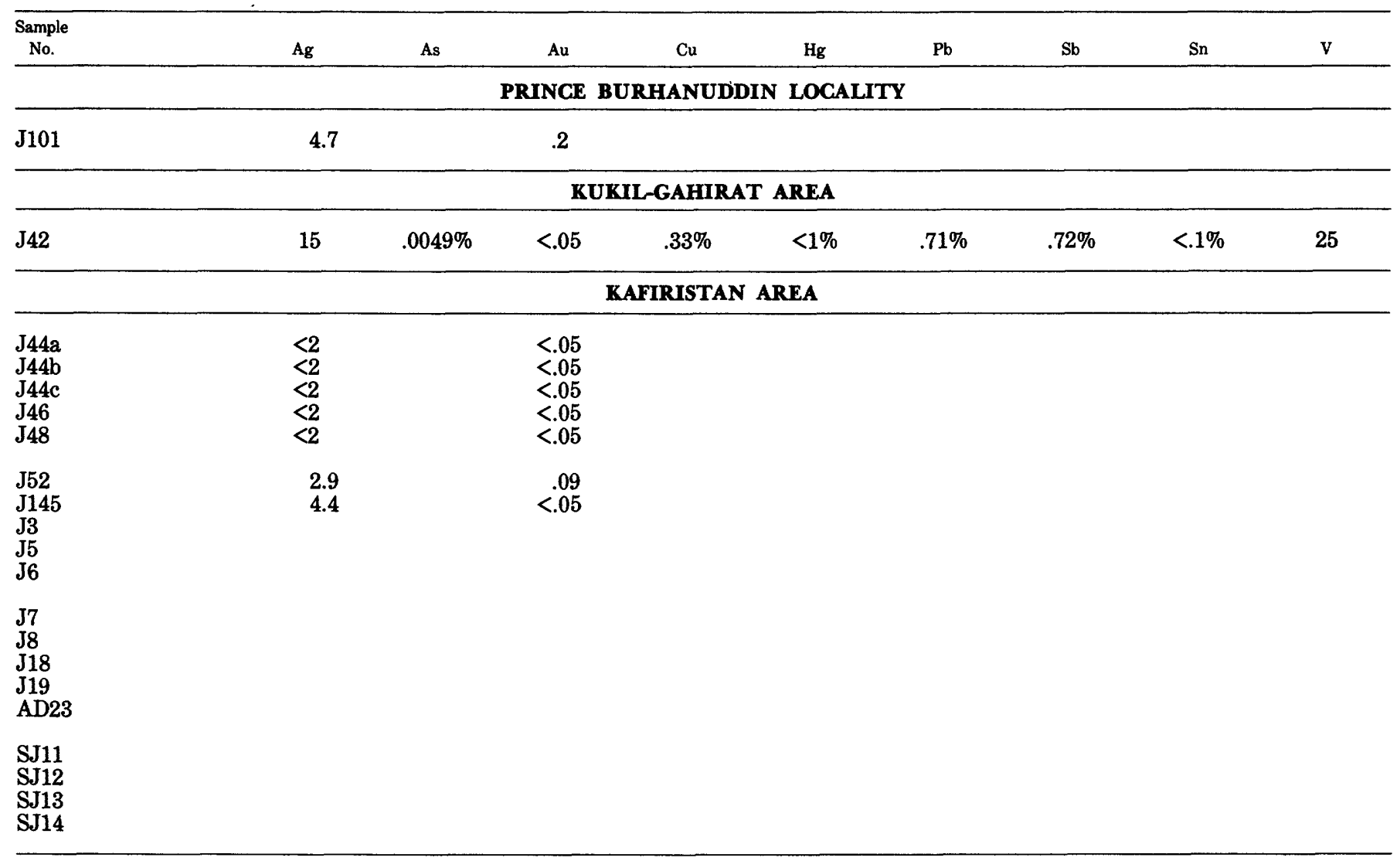

DROSH-SHISHI VALLEY AREA

\begin{tabular}{|c|c|c|c|c|c|c|c|c|c|}
\hline $\begin{array}{l}\mathrm{J} 102 \\
\mathrm{~J} 102 \mathrm{a} \\
\mathrm{J} 104 \\
\mathrm{~J} 143 \\
\mathrm{~J} 144 \mathrm{a}\end{array}$ & $\begin{array}{l}16 \\
<2 \\
\\
<2 \\
55\end{array}$ & $.01 \%$ & $\begin{array}{c}<.05 \\
<.05 \\
\\
.4 \\
1.3\end{array}$ & $2.0 \%$ & $<1 \%$ & $<.05 \%$ & $<.5 \%$ & $<.1 \%$ & 30 \\
\hline $\begin{array}{l}\mathrm{J} 144 \mathrm{~b} \\
\mathrm{~J} 148 \mathrm{a} \\
\mathrm{J} 148 \mathrm{~b} \\
\mathrm{~J} 148 \mathrm{c} \\
\mathrm{J} 148 \mathrm{~d}\end{array}$ & $\begin{array}{r}<10 \\
<2 \\
<2 \\
<2 \\
<2\end{array}$ & $.006 \%$ & $\begin{array}{c}.05 \\
<.05 \\
.1 \\
<.05 \\
.2\end{array}$ & $2.6 \%$ & $<1 \%$ & $<.05 \%$ & $<.5 \%$ & $<.1 \%$ & .62 \\
\hline $\begin{array}{l}\text { J148e } \\
\text { J148f } \\
\text { J149a } \\
\text { SJ38 } \\
\text { SJ39 }\end{array}$ & $\begin{array}{c}<2 \\
<2 \\
4.6 \\
<10 \\
<10\end{array}$ & $\begin{array}{l}.0085 \% \\
.014 \%\end{array}$ & $\begin{array}{c}<.05 \\
<.05 \\
.1 \\
<.05 \\
<.05\end{array}$ & $\begin{array}{c}3.5 \% \\
.56 \%\end{array}$ & $\begin{array}{l}4 \\
4\end{array}$ & $\begin{array}{l}<.05 \% \\
<.05 \%\end{array}$ & $\begin{array}{l}<.5 \% \\
<.5 \%\end{array}$ & $\begin{array}{l}<.1 \% \\
<.1 \%\end{array}$ & $\begin{array}{r}170 \\
82\end{array}$ \\
\hline $\begin{array}{l}\text { SJ44 } \\
\text { SJ46 } \\
\text { SJ49 } \\
\text { SJ141 } \\
\text { SJ193 }\end{array}$ & $\begin{array}{r}25 \\
60 \\
<2 \\
1700 \\
<2\end{array}$ & $\begin{array}{l}.0042 \% \\
2.4 \%\end{array}$ & $\begin{array}{l}<.05 \\
.3 \\
.15 \\
4.3 \\
.2\end{array}$ & $\begin{array}{l}9.3 \% \\
8.9 \%\end{array}$ & $\begin{array}{l}4 \\
4\end{array}$ & $\begin{array}{l}<.05 \% \\
39.5 \%\end{array}$ & $\begin{array}{l}<.5 \% \\
5.6 \%\end{array}$ & $\begin{array}{l}<.1 \% \\
<.1 \%\end{array}$ & $\begin{array}{l}78 \\
30\end{array}$ \\
\hline
\end{tabular}

SJ205 


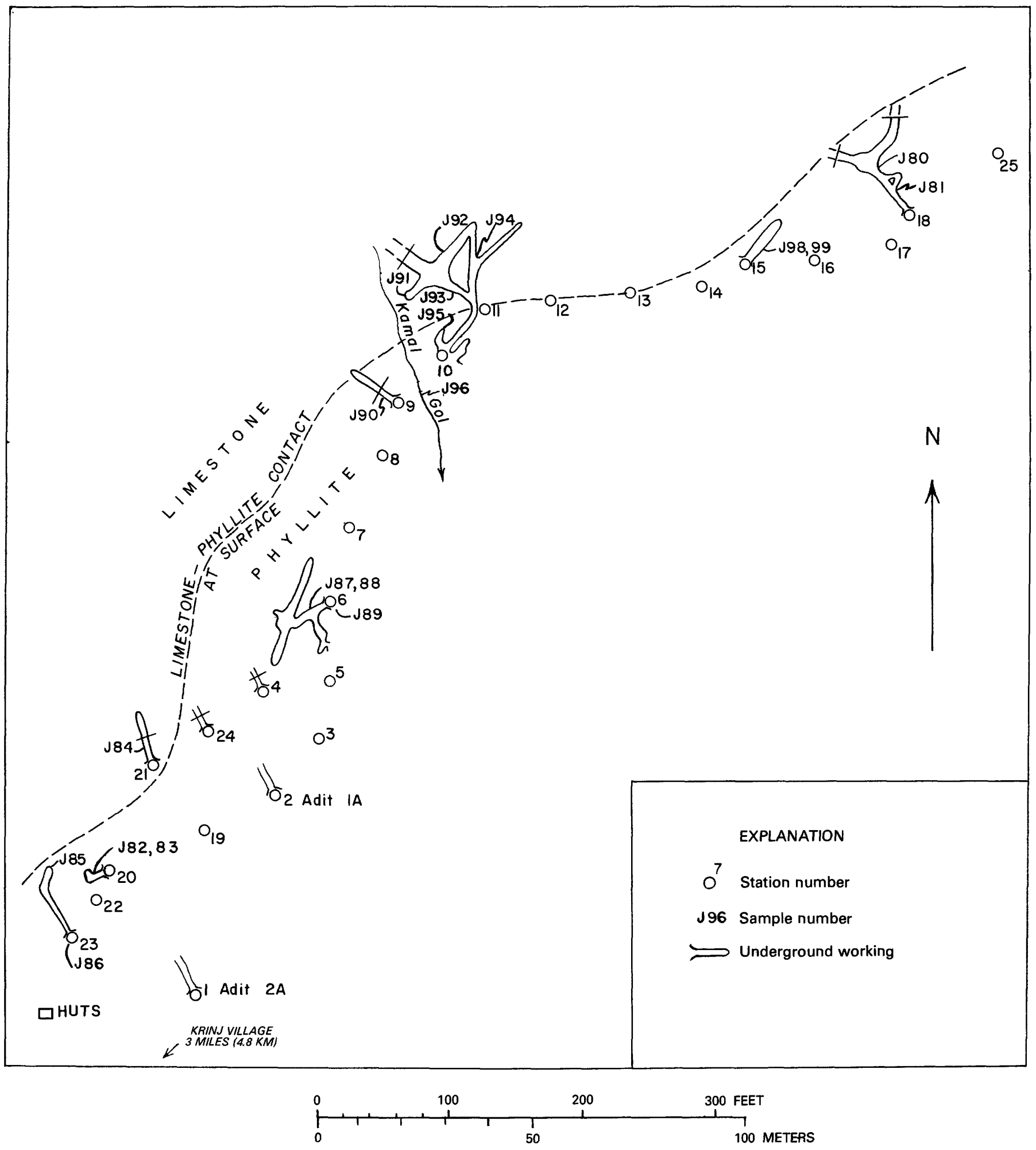

FIGURE 5.-Tape-compass survey map of the Krinj (Kamal Gol) mine area, Chitral Mining Co., Ltd. 
Mining has always been done on a relatively small scale by hand labor, using primitive hand tools and working by the feeble light of homemade oil lamps. Production from 1939 through 1968 is as follows:

Year
1939
1940
1942
1943
1946
1947
1956
1957
1958
1969
1961
1962
1964
1965
1966

Production
(sturt tons)
550
650
200
300
Not available
584
378
Closed
156
164
36
152
89
15
95
9
90
67
50 est.
50 est.
50 est.

1 Production figures provided by the Pakistan Directorate of Mineral Development, Lahore, Pakistan.

In 1969, mining was being done by three to four miners who climbed $2,500 \mathrm{ft}(610 \mathrm{~m})$ to the mines in the early morning, mined a man-load of ore (160-200 lbs.) $(60-75 \mathrm{~kg})$ and moved it down to the retort, either on their backs or on wooden sleds. At the minesite were several huts, a diesel engine, and a small workshop. The diesel engine was used occasionally to dewater the mine and to circulate fresh air. Only the watchman lived at the minesite full time; the rest of the workers returned to Krinj village at the end of the day. The main camp at Krinj village consisted of several huts, the mine office and the retort plant. The staff included the resident geologist, a secretary, driver, three retort operators, a general-purpose mechanic, and some servants.

The 1969 price obtained for the antimony oxide at Karachi was approximately Rs. 160.00/Maund $(\$ 0.40 / \mathrm{lb})$. Information is not available on the overall costs, but they must have been considerable and the margin of profit probably was small.

\section{GEOLOGY}

A system of quartz-stibnite veins has been emplaced in the Chitral Slate at and near the faulted contact between the slate and the overlying limestone and marble of the Reshun Formation. The veins follow shear zones which, with one exception, are part of the main fault along the contact, or they are branch faults subsidiary to the main fault.
On a regional scale, the geologic structure follows a northward course as far as the Lutkho River and is characterized by steeply dipping reverse faults and rock units. North of the Lutkho River, the structure swings northeast and east, becomes sharply overturned toward the south and, east of the Krinj mine area, the Reshun and Krinj reverse faults change to low and moderately dipping thrust faults. In the mine area, therefore, and for a long distance eastward, the overturned older limestone rests upon the younger slate along a northward-dipping thrust fault, and the rocks as well as the veins dip northward at moderate angles. The sharp turn in the strike and the associated transition from reverse to thrust faulting forms the locus of the antimony veins. This favored site of vein deposition is suggested to be the result of relative dilation along the main fault in the interval where the sharp change in strike takes place. The difference in competence between the limestone and slate also would be likely to accentuate a condition of relative dilation along this interval.

\section{KAMAL GOL MINE}

The Kamal Gol mine is at the foot of a limestone escarpment 1 mile $(1.6 \mathrm{~km})$ northeast of Krinj at $7,700 \mathrm{ft}$ $(2,347 \mathrm{~m})$ (lower adit). All present production comes from this mine, as did most of the production of the past.

The main workings presently accessible consist of two adits, called adits $2 \mathrm{~A}$ and $1 \mathrm{~A}$ (fig. 6), and numerous pits and smaller adits spread over a distance of $900 \mathrm{ft}$ $(274 \mathrm{~m})$ along the base of the limestone escarpment northeast of the main adits (fig. 5). Adit $2 \mathrm{~A}$ is about 750 $\mathrm{ft}(229 \mathrm{~m})$ and adit $1 \mathrm{~A}$ about $250 \mathrm{ft}(76 \mathrm{~m})$ long. Former workings of substantial size are located $400 \mathrm{ft}(122 \mathrm{~m})$ below and to the southwest of adit $2 \mathrm{~A}$, but these were caved and therefore inaccessible.

The lower main adit, $2 \mathrm{~A}$, is driven $\mathrm{N}$., $30^{\circ} \mathrm{W}$. into barren slate and phyllite and was expected to intersect the southwestward continuation of the quartz-stibnite vein at 200 to $250 \mathrm{ft}(61-76 \mathrm{~m})$. At $200 \mathrm{ft}(61 \mathrm{~m})$, the fault zone was intersected, but the mineralized vein was not found. The adit was extended for another $195 \mathrm{ft}(59 \mathrm{~m})$ through the fault zone, but only a few thin and barren quartz veins were found. Evidently, the main vein pinches out to the southwest before reaching the adit. The adit was then driven $150 \mathrm{ft}(46 \mathrm{~m})$ in a northeasterly direction through barren slate to provide level access to the earlier workings of the former operators. The former workings in the mineralized zone consist of a system of large open stopes extending upward at a $45^{\circ}$ angle along the vein. These old workings are now partly boarded up, partly caved and near the point of complete collapse. They are considered unsafe and are not entered by the present-day workers. Because of the 


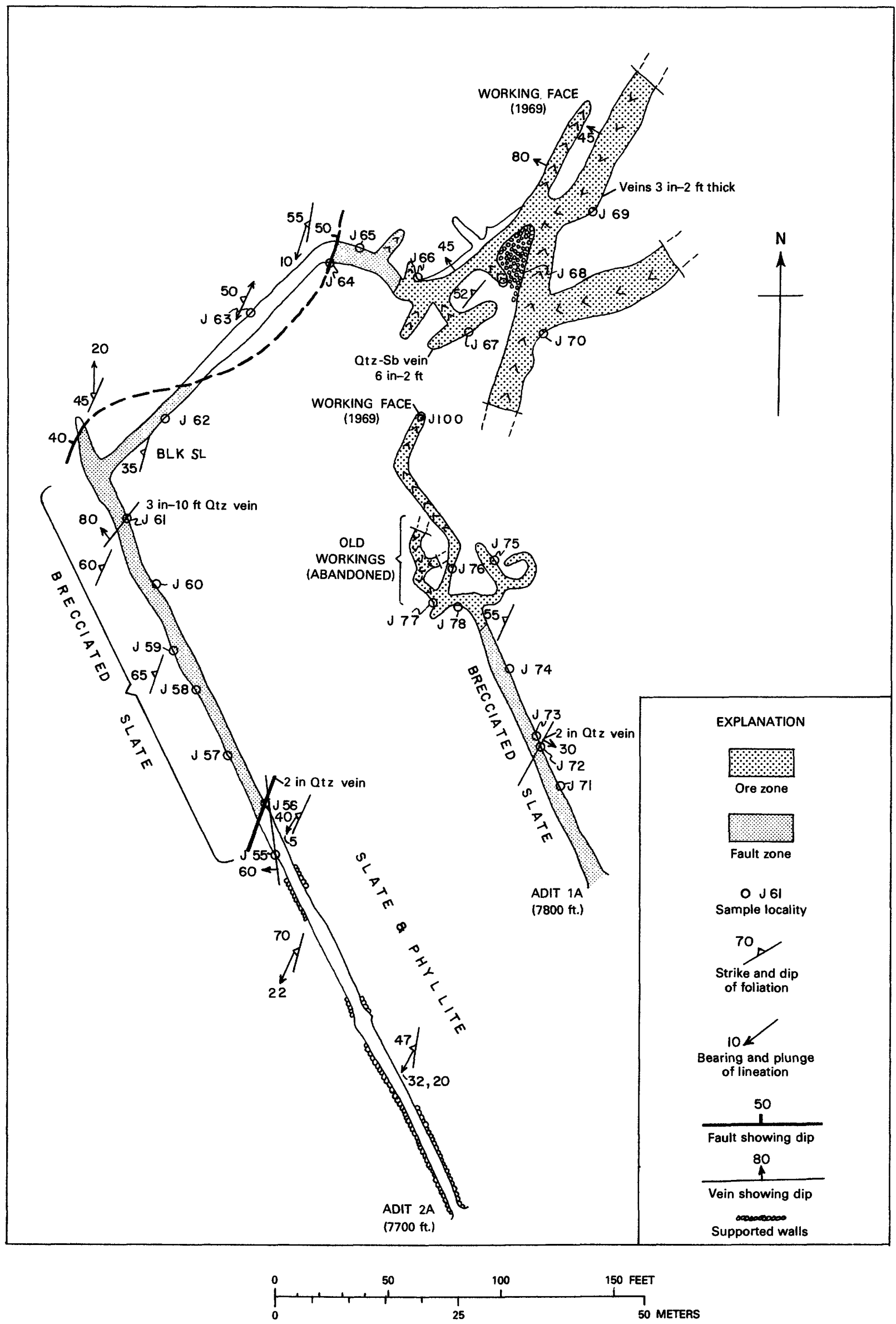

FIguRE 6.-Plan map of Krinj (Kamal Gol) Mine, Chitral Mining Co., Ltd. Quartz-stibnite (Q-sb) veins alternating with slate. 
heavy ground and difficulty of access, the present survey party entered these stopes only for short distances. The stopes followed a quartz-stibnite vein system a few inches to more than $5 \mathrm{ft}(1.5 \mathrm{~m})$ wide composed of alternating country rock and vein material. Stibnite content rangesfrom 30 to 60 percent and veins of pure stibnite are as much as 12 inches $(0.3 \mathrm{~m})$ thick. At the sample locality J66 (fig. 6), the vein was 3 to 4 inches $(7.6-10.2 \mathrm{~cm})$ thick; at J69 and J70, it was 4 to $6 \mathrm{ft}$ $(1.2-1.8 \mathrm{~m})$ thick and composed of about 60 precent stibnite. In spite of the fact that rich ore continues upward, the stopes had to be abandoned because of the heavy ground.

The present mining is being done adjacent to the old workings along the downward extension of the vein, which at this point becomes steeply inclined to $80^{\circ}$. The drift slopes downward in a direction parallel to the slope of the old stopes, and in 1967 was driven $60 \mathrm{ft}(18 \mathrm{~m})$ along the vein. In 1968, this inclined drift had been extended considerably. Because of the downward incline of this adit, the lack of fresh air at the working face was becoming a serious problem. At the time of the underground survey, the drift was full of water and, therefore, inaccessible.

The upper adit, $1 \mathrm{~A}$, is $100 \mathrm{ft}(30 \mathrm{~m})$ above and $150 \mathrm{ft}$ $(46 \mathrm{~m}) \mathrm{N} .25^{\circ} \mathrm{E}$. of adit $2 \mathrm{~A}$, and is driven N. $30^{\circ} \mathrm{W}$. into slate and phyllite. Little useful information was obtained from this adit. The adit is driven through the fault zone for $140 \mathrm{ft}(43 \mathrm{~m})$, at which point the quartz-stibnite vein is intersected. Beyond the point where the vein begins are numerous winding drifts that narrow to tiny crawl spaces. The ground is heavy, generally unsupported, and, therefore, unsafe. The main ore drift, inclined downward, follows the dip of the vein in a general northward direction for about $130 \mathrm{ft}(40 \mathrm{~m})$ and is the present working face. At sample locality J76, the drift was largely filled in by a roof fall, and it was considered unsafe to proceed to the working face. A sample of ore from the working face (J100) was obtained from the miners. At J77, a sinuous lateral drift, inclined upward, extends to the west above the main drift. It splits into two drifts after $20 \mathrm{ft}(6 \mathrm{~m})$, and both splits are caved a short distance beyond. Another short lateral drift followed the vein to the east side of the main drift. A discrete vein was not seen in place in this adit, probably because the vein and country rock have been thoroughly ground up into fault gouge and breccia. Numerous outcrops of brecciated ore were available for samples, however, and the various drifts obviously follow the ore zone.

The locations of specimens collected in adits $2 \mathrm{~A}$ and $1 \mathrm{~A}$ are shown in figure 6; results of analyses are tabulated in tables 1 and 2 . In addition to antimony, which constitutes the bulk of the ore, the analyses show small amounts of silver, gold, copper, lead, vanadium, and some show zinc. Silver is present, mainly in trace amounts, but the spectrographic analyses of a few samples of the ore show a range from 10 to $70 \mathrm{ppm}$. Chemical analyses, on the other hand, show a maximum of only $5 \mathrm{ppm}$ silver. Gold content ranges from traces to $4.3 \mathrm{ppm}$, yielding the highest values from the adjacent country rock and from small, otherwise barren, quartz veins. The quantity of base metals is too small to be considered significant.

Besides the two main adits, numerous old pits and adits, some of moderate length, dot the hillside between adit $2 \mathrm{~A}$ and a point $900 \mathrm{ft}(274 \mathrm{~m})$ to the northeast. A tape-compass survey of these workings is shown in figure 5. These workings mark the surface outcrop of the main antimony vein, and it is seen that the vein is at or slightly below the contact between limestone above and slate-phyllite below. Many of these workings are short tunnels, many of them caved, that followed small antimony showings. A few of them are more elaborate, however, with several hundred feet of workings. At station 10, the workings are of considerable extent, and they provide some useful information on the disposition of the antimony veins. Station 10 is in the fault zone 20 $\mathrm{ft}(6 \mathrm{~m})$ below the limestone. The entrance opens immediately into a room $25 \mathrm{ft}(7.7 \mathrm{~m})$ across, $20 \mathrm{ft}(6 \mathrm{~m})$ from front to back, and 5 feet $(1.5 \mathrm{~m})$ from floor to ceiling. This room probably was occupied by a large pocket of ore. From the back of the room a drift, inclined downward, is driven in a northeasterly direction along a vein system 2 to $5 \mathrm{ft}(0.6-1.5 \mathrm{~m})$ thick. At $40 \mathrm{ft}(12 \mathrm{~m})$ from the entrance, the drift turns north and slopes downward $22^{\circ}$. Just beyond the turn, the workings split into two drifts, one continuing northward on the vein system, the other taking a northwesterly direction down the $40^{\circ}$ dip of the vein system. A quartz-stibnite vein $5 \mathrm{ft}$ $(1.5 \mathrm{~m})$ thick can be seen to narrow along the northern wall of this northwest-trending drift down to -2 inches $(5 \mathrm{~cm})$ in a distance of $25 \mathrm{ft}(7.6 \mathrm{~m})$. Ten $\mathrm{ft}(3 \mathrm{~m})$ above the pinchout point, a second vein begins; the rest of the workings followed this latter vein, which consists of several parallel quartz-stibnite veinlets and stringers separated by slate and phyllite. It appears, therefore, that in the workings of station 10 , the vein system is made up of a series of individual lens-shaped veins arranged en echelon.

A second moderate-sized old working is located at station 18 at the eastern end of the area. An adit driven N., $40^{\circ} \mathrm{W}$. follows a vein down the $30^{\circ}$ dip of the overlying sheared phyllite. At $50 \mathrm{ft}(15 \mathrm{~m})$ the tunnel opens into a large, partly caved room $25 \mathrm{ft}(7.6 \mathrm{~m})$ long, $15 \mathrm{ft}(4.6 \mathrm{~m})$ wide, and $12 \mathrm{ft}(3.7 \mathrm{~m})$ high. At the west and east ends of the room are steeply inclined, inaccessible shafts that continue downward, reportedly for distances of $150 \mathrm{ft}$ 
$(46 \mathrm{~m})$ and $200 \mathrm{ft}(61 \mathrm{~m})$, respectively. In 1968, some exploratory work was done in these workings but no new ore was found, and the work was stopped.

Samples collected from these old workings are indicated in figure 5 , and the results of analyses are shown in tables 1 and 2 . The results of the analyses are similar to those from the main adits. Besides antimony, the samples contain small amounts of silver and gold plus base metals. The maximum gold content is $3.4 \mathrm{ppm}$ and, as in the main adits, the highest gold values are found in otherwise barren quartz veins and in the altered phyllite adjacent to the veins. Silver ranges from traces to 70 $\mathrm{ppm}$, the latter value found in an otherwise barren quartz vein. The most interesting specimen is one about which the least is known, J96, a piece of copper-greenstained phyllitic limestone float taken from Kamal Gol. This specimen, which is not a stibnite ore, contains more than 10 percent copper and $200 \mathrm{ppm}$ silver by spectrographic analysis, and $115 \mathrm{ppm}$ silver by chemical analysis. The exact source of this specimen is not known, but it could only have come from the rocky crags above the mine within the very restricted area drained by Kamal Gol. The cliffs above the mine probably have never been prospected, as access to them is very difficult.

\section{BAKHT GOL MINE}

The Bakht Gol mine is on a steep, nearly inaccessible, southeast facing slope 1 mile $(1.6 \mathrm{~km})$ northeast of the Kamal Gol mine at an altitude of 8,600 ft (2,621 m). Access is from the Krinj mine along a difficult footpath that slopes steeply upward from the Krinj mine, crosses a saddle, then follows the precipitous northeast-facing slope above Bohrtuli to the mine.

Information obtained by the present survey party is based upon a brief visit in November 1967. A more detailed study planned in 1968 was abandoned because the footpath along the northeast-facing slope was taken out by an avalanche.

The guide from Krinj states that the mine was opened in 1937 by locals and was leased in 1940 by the Pardkh Verani Mining Syndicate operating the Krinj mine. The mine was worked until 1947. Exploration was resumed by the Chitral Mining Co. in 1966 and 1967, but no further work was done in 1968.

The old workings consist of a single adit, inclined $30^{\circ}$, driven S., $50^{\circ} \mathrm{W}$. along a vertically dipping brecciated quartz-stibnite vein that cuts black slate. The faulted contact between the slate and the overlying limestone is at least $400 \mathrm{ft}(122 \mathrm{~m})$ vertically above the workings. The faulted contact, therefore, has no direct relationship with this deposit. The adit opens immediately into a large stope or room, $13 \mathrm{ft}(4 \mathrm{~m})$ wide, $15 \mathrm{ft}(4.6 \mathrm{~m})$ high and $40 \mathrm{ft}(12 \mathrm{~m})$ along the inclined length. The floor is covered by a thick layer of debris from roof falls. The left side of the stope, which is slate, forms a smooth, straight wall trending S., $65^{\circ} \mathrm{W}$., and dipping $80^{\circ} \mathrm{N}$., on which slickensides plunge $70^{\circ} \mathrm{SW}$. The slate country rock dips at a low but variable angle, and inside the stope the adjacent slate is folded into pencil structures (rodding) having a bearing of S., $35^{\circ} \mathrm{W}$. and a plunge of $5^{\circ} \mathrm{SW}$. White, yellow, black, and red encrustations coat the roof and sides of the stope. No ore was seen, but evidently the stope contained a thick lens of ore. At the bottom of the inclined stope is a partly filled tunnel, mostly filled by fallen rock, leading to lower workings of unknown extent.

Exploratory work in 1966-67 was done along the quartz vein 30 to $50 \mathrm{ft}(9-15 \mathrm{~m})$ downslope from the old workings. These exploratory workings include an adit $55 \mathrm{ft}(17 \mathrm{~m})$ long driven $\mathrm{S}$., $50^{\circ} \mathrm{W}$., and two short adits 5 $\mathrm{ft}(1.5 \mathrm{~m})$ and $10 \mathrm{ft}(3 \mathrm{~m})$ long. These workings are along the quartz vein and brecciated slate zone. In the longer adit, the brecciated slate contains numerous discontinuous lenses and veinlets of quartz but no visible sulfide ore. In 1967, a new adit, $150 \mathrm{ft}$ (46 m) south of the exploratory adit, was being driven in a northwesterly direction in an attempt to intersect the lower part of the old workings. However, it was only started in November 1967 , and no work was done in 1968. Mukti Nath (1944) states that at the time of his visit in 1944 , an adit $90 \mathrm{ft}$ $(27 \mathrm{~m})$ long was following a quartz vein 2 to $4 \mathrm{ft}(0.6-1.2$ $\mathrm{m})$ thick containing stringers of stibnite.

\section{RESERVES}

Reserves are difficult to figure accurately because of the variable thickness and patchy distribution of the ore. However, a rough estimate can be made of the reserves in the immediate vicinity of adits $2 \mathrm{~A}$ and $1 \mathrm{~A}$ of the Krinj (Kamal Gol) mine, if the ore is assumed to form a sheet 2 $\mathrm{ft}(0.6 \mathrm{~m})$ thick. This assumption is probably reasonable in view of the fact that in this immediate area, the vein commonly is $6 \mathrm{ft}(1.8 \mathrm{~m})$ thick and seldom decreases to 1 $\mathrm{ft}(0.3 \mathrm{~m})$.

Indicated reserves include the volume of ore between adits $2 \mathrm{~A}$ and $1 \mathrm{~A}$, minus the ore already mined out. The specific gravity of the ore is found to be 3.39 , so 1 ton of ore occupies 9.4 cubic $\mathrm{ft}\left(0.26 \mathrm{~m}^{3}\right)$. The indicated reserves are therefore:

$$
\begin{aligned}
& 2 \mathrm{ft} \times 150 \mathrm{ft} \times 300 \mathrm{ft} \\
& \frac{\underset{\text { thickness })}{2 \mathrm{ft}} \times \begin{array}{c}
150 \mathrm{ft} \\
\text { (dip length) }
\end{array}}{9.4 \mathrm{ft}^{3}}=\begin{array}{c}
300 \mathrm{ft} \\
(\text { strike length })
\end{array}=\begin{array}{c}
9,500 \text { short tons } \\
(8,617 \text { metric tons })
\end{array}
\end{aligned}
$$

Of this 9,500 short tons, 4,000 tons have been mined thus far leaving:

9,500 tons $-4,000$ tons $=5,500$ tons $(4,989$ metric tons $)$ of indicated ore. 
Reserves of inferred ore are much larger. This class of reserves assumes that the ore extends another $150 \mathrm{ft}$ downdip and is continuous along the $400 \mathrm{ft}$ of strike length between a point 50 feet southwest of adit $1 \mathrm{~A}$ and the workings of station 10 . On this basis, the inferred reserves are:

$$
\begin{array}{r}
\frac{2 \mathrm{ft} \times 300 \mathrm{ft} \times 400 \mathrm{ft}}{9.4 \mathrm{ft}^{3}}-4,000 \text { tons }=21,000 \text { tons }(19,068 \\
\text { metric tons }) \text { of inferred ore }
\end{array}
$$

Although these reserves are relatively small, at the present rate of production they are sufficient for 20 to 30 years of operations.

\section{PARTSAN AREA}

The Partsan area, which is 4 miles $(6.4 \mathrm{~km})$ northeast of the Krinj mines, forms a circular high-level basin rimmed on all sides by mountain ridges. From Partsan village at an altitude of $9,300 \mathrm{ft}(2,835 \mathrm{~m})$ the ground rises steeply to $13,000 \mathrm{ft}(3,962 \mathrm{~m})$ on the north rim, $11,000 \mathrm{ft}(3,353 \mathrm{~m})$ on the west and south rims, and nearly $14,000 \mathrm{ft}(4,267 \mathrm{~m})$ on the east rim. The creek draining the basin flows southwestward, cutting a deep gorge through the limestone of the south rim. The main access to Partsan is by a steep footpath 5 miles $(8 \mathrm{~km})$ long that follows the southwesterly flowing creek.

The Partsan area is underlain by Devonian to Jurassic rocks, which trend northeast and dip at low to moderate angles to the north. Low-grade metamorphic rocks prevail in the Partsan area and include black phyllite, fine-grained calcareous quartz schist, and fine-grained, partly recrystallized limestone and dolomite. These latter rocks form the prominent high ridges of the east and south rims. The overall structure consists of a northeasttrending anticline, overturned southward, and faulted against the Cretaceous rocks of the south rim.

The mineral showings in the Partsan area include the Partsan antimony mine, now closed; an antimony locality on the east rim; and two copper-antimony localities.

\section{PARTSAN ANTIMONY MINE}

The Partsan antimony mine is a small mine on a knoll 1 mile $(1.6 \mathrm{~km})$ northeast of Partsan village at an altitude of $10,100 \mathrm{ft}(3,078 \mathrm{~m})$. It is entirely within the Sarikol Shale forming Partsan basin and there is no evident geological connection between this mine and the Krinj mines previously described. A small but unknown quantity of antimony ore was mined in the early 1940's; the mine has been closed ever since. Time and shifting ground have nearly covered all traces of the workings. All that remains is a largely filled opencut $25 \mathrm{ft}(7.6 \mathrm{~m})$ long trending N., $40^{\circ}$ E. A slight topographic depression continuing for another 240 feet $(73 \mathrm{~m})$ to the northeast and for $300 \mathrm{ft}(91 \mathrm{~m})$ to the southwest probably represents the continuation of the opencut. No ore was found either in the trench or on the remains of a sizable dump littering the south slope of the knoll. The northwestern side of the opencut consists of a bed of brownstrained quartzite $4 \mathrm{ft}(1.2 \mathrm{~m})$ thick cut by irregular quartz veins. The surrounding country rock, which belongs to the Sarikol Shale, is black micaceous, brownweathering, pyritized phyllite containing scattered quartz veins and stringers.

Analyzed specimens of the quartzite, quartz veins, and altered country rock (tables 1 and 2, J36a, b, c, d), taken from the opencut and vicinity, show only traces of gold and silver and no unusual amounts of the base metals. Judging from the dimensions of the cut and the remains of the dump, the amount of ore mined probably was of the order of 100 to 200 metric tons.

\section{EAST RIM ANTIMONY LOCALITY}

A small showing of antimony-zinc ore is located high on the east rim 1 mile $(1.6 \mathrm{~km})$ east of Partsan village at $11,950 \mathrm{ft}(3,642 \mathrm{~m})$. The showing is in dolomite of the Devonian unit adjacent to the altered, faulted contact between black phyllite of the Sarikol Shale on the west and gray dolomite on the east. The dolomite, which strikes N., $45^{\circ} \mathrm{E}$. and dips $80^{\circ} \mathrm{NW}$., forms a sheer wall extending to the top of the ridge $1,000 \mathrm{ft}(305 \mathrm{~m})$ above. Irregular veins of stibnite ore 0.5 inch to 8 inches $(1.2-20 \mathrm{~cm})$ thick follow small shears and fractures in the dolomite. The veins tend to follow the bedding in the dolomite, but they also follow irregular small shears and fractures trending in various directions. The only workings are a small opencut $5 \mathrm{ft}(1.5 \mathrm{~m})$ long in the cliff face and a small pit $3 \mathrm{ft}(0.9 \mathrm{~m})$ deep dug on a lenticular pod of ore. One vein 8 inches $(20 \mathrm{~cm})$ wide extends in irregular fashion up the nearly vertical cliff face as far as could be seen $(30-40 \mathrm{ft})(9-12 \mathrm{~m})$. The ore is stained yellow, orange, and red, but no green or blue copper staining was seen. Analyses of ore specimens (J24b, c) show a predominance of antimony and small amounts of zinc ( 0.1 percent), copper ( 0.05 percent), and lead ( 0.05 percent). Reserves appear insignificant.

\section{COPPER-ANTIMONY SHOWINGS}

One copper-antimony showing is near the south rim 1 mile $(1.6 \mathrm{~km})$ west of Partsan village along the faulted contact between the Reshun Formation on the south and black micaceous phyllite of the Sarikol Shale on the north. Thin, lenticular quartz veins containing copperstained black sulfide ore are widely scattered in a bed of brecciated dolomite. No significant amount of ore is in sight, but the locality is interesting because analysis of the ore (J38) shows $1,000 \mathrm{ppm}$ silver, $16 \mathrm{ppm}$ gold, 7 percent lead, 1,000 ppm zinc, and small amounts of copper and antimony. 
Another copper-antimony showing is 1 mile $(1.6 \mathrm{~km})$ northeast of Partsan and $500 \mathrm{ft}$ (152 m) northwest of the Partsan antimony mine. This showing is a large mineralized, copper-stained boulder (float) of silicified carbonate rock containing stibnite in small irregular veinlets. Possibly, this boulder came from the Partsan antimony mine, but more likely it came from a point farther north along the east rim. A spectrographic analysis of the ore shows mainly antimony with small amounts of copper, lead, and zinc.

At a third locality, a boulder of altered limestone rock was collected from a talus pile at an altitude of $11,250 \mathrm{ft}$ $(3,429 \mathrm{~m})$, about $1,000 \mathrm{ft}(305 \mathrm{~m})$ below the east rim antimony locality. Spectrographic analyses (J25) show 3 percent zinc, traces of lead and copper, and no antimony. The metal content is different from that of the east rim antimony locality, so this boulder probably comes from a different source along the east rim.

\section{SHOGHOT-MADASHIL AREA}

The Shoghot-Madashil area comprises a narrow mineralized zone extending from the junction of two faults at Shoghot, northeastward to Madashil (pl. 1, figs. $3,4)$. This zone is the northeastward extension of the Awireth Gol locality. Two localities were found, one at Shoghot and one at Madashil. Analytical information on samples collected from these localities is contained in tables 1 and 2.

\section{SHOGHOT LOCALITY}

The Shoghot locality is $800 \mathrm{ft}(244 \mathrm{~m})$ above Shoghot on the steep rocky slopes east of Ojhor Gol. It lies along the Pasti fault that separates the Sarikol Shale on the east from the other Devonian to Jurassic rocks on the west. The fault is a mineralized, brown-weathering, gossanlike breccia zone 45 to $50 \mathrm{ft}(14-15 \mathrm{~m})$ thick consisting of iron-rich, jasperoid-carbonate rock. Individual minerals are crystalline secondary dolomite, pyrite, and small amounts of chalcopyrite, galena, and secondary malachite. No prospecting work has been done. An analysis of the brown gossanlike breccia (J141b) shows 2 ppm gold, but only small amounts of copper, lead, zinc, silver, and antimony. Two other samples of the brecciated zone (J141a, J141c) show only small amounts of base and precious metals.

Three hundred feet further upslope at an altitude of $7,450 \mathrm{ft}(2,271 \mathrm{~m})$, a second fault,' the Reshun fault, separates the dolomite cliffs of the Reshun Formation from the Sarikol Shale. At this place, it was possible to climb the cliffs only to within about $200 \mathrm{ft}(61 \mathrm{~m})$ of this fault, but float of brecciated, malachite-stained dolomite indicates copper mineralization along it, also. An analysis of this float (J141d) shows $3.6 \mathrm{ppm}$ silver and small amounts of copper, lead, and gold.
MADASHIL LOCALTITY

The Madashil locality is a half mile $(0.8 \mathrm{~km})$ southwest of Madashil Village on the northwest-facing cliffs at $8,350 \mathrm{ft}(2,545 \mathrm{~m})$. It lies on the northeastern continuation of the Pasti fault (pl. 1). Two localities $500 \mathrm{ft}(152 \mathrm{~m})$ apart were investigated.

The first and southwesternmost locality is a mineralized breccia zone directly underlying a bed of thinbanded white marble. The marble strikes N., $80^{\circ} \mathrm{E}$, dips $35^{\circ}$ N., and is an interbed within the Sarikol Shale. Directly below the marble, a mineralized zone 12 to 14 inches $(30-36 \mathrm{~cm})$ thick contains discontinuous pods and stringers of galena 6 to 10 inches $(15-25 \mathrm{~cm})$ long and 3 to 6 inches $(8-15 \mathrm{~cm})$ thick. A small excavation $15 \mathrm{ft}$ $(4.6 \mathrm{~m})$ long has been dug along the galena stringers. This mineralized zone crops out for about $150 \mathrm{ft}(46 \mathrm{~m})$ along the general trend of the bedrock, beyond which the zone is covered by talus. Pyritized secondary crystalline dolomite, red pyritized jasper, and veins of quartz underlie the galena veins. Analysis of the lead ore (J140a) shows 53.5 percent lead, 0.14 percent copper, and 0.2 percent zinc, $0.3 \mathrm{ppm}$ gold, and small amounts of antimony, arsenic, silver, and tin.

The second locality investigated is exposed on the steep slope $500 \mathrm{ft}(152 \mathrm{~m})$ northeast of the first locality and probably lies along the continuation of the same mineralized fault zone. The shear zone strikes $\mathrm{N}$., $50^{\circ}$ E., dips $60^{\circ} \mathrm{N}$., and is at least $300 \mathrm{ft}(91 \mathrm{~m})$ wide. It consists mainly of sheared black phyllite with beds of brown-weathering, thick-bedded phyllitic dolomite. Within this wide shear zone is a mineralized zone about $30 \mathrm{ft}(9 \mathrm{~m})$ thick containing quartz-carbonate veins and stringers. Galena and pyrite in small veinlets and patches are associated with quartz, brown ankeritic dolomite, and phyllite fragments. Secondary malachite and azurite also are present, but no primary copper ore was seen. An analysis of a mineralized sample (J140d) shows 0.50 percent copper, 0.72 percent lead, 1.0 percent antimony, $0.6 \mathrm{ppm}$ gold, and small amounts of silver.

\section{PRINCE BURHANUDDIN LOCALITY}

The Prince Burhanuddin locality is 8 miles $(13 \mathrm{~km})$ north of Chitral on the east bank of the Lutkho River, $200 \mathrm{ft}(61 \mathrm{~m})$ upslope from the Prince's hunting lodge. The locality is a $3-\mathrm{ft}(0.9 \mathrm{~m})$ quartz vein containing in one place a small amount of chalcopyrite and secondary malachite. The vein, which cuts the Chitral Slate, strikes N., $60^{\circ} \mathrm{W}$., about perpendicular to the strike of the slate, and dips vertically. It extends for $70 \mathrm{ft}(21 \mathrm{~m})$ to the southeast and down the steep slope to the northwest for $120 \mathrm{ft}(37 \mathrm{~m})$ where it goes under talus. In places, the vein contains vugs partly filled with quartz crystals. In other places, the vein is highly sheared and fractured by movement. Slickensides resulting from shearing move- 
ments plunge $20^{\circ} \mathrm{SW}$. An analysis of a sample of the quartz-copper ore (J101) shows $4.7 \mathrm{ppm}$ silver, 3 percent copper, and small amounts of lead, zinc, and gold. There are no reserves at this locality.

\section{KUKIL-GAHIRAT AREA}

KUKIL LOCALITY

The Kukil locality is near Kukil village, 4 miles (6.4 $\mathrm{km}$ ) east of Chitral on the north side of Jughur Gol at an altitude of 7,800 $\mathrm{ft}(2,377 \mathrm{~m})$. A small pit has been dug on a quartz vein containing small amounts of chalcopyrite, galena, and pyrite in veinlets and in small vugs. The vein, which is 6 to 10 inches $(15-25 \mathrm{~cm})$ thick, strikes N., $15^{\circ}$ E. and dips $70^{\circ}$ E., parallel to the enclosing phyllites of the Chitral Slate. Analysis of the ore (J42) shows $15 \mathrm{ppm}$ silver, 0.33 percent copper, 0.7 percent lead, 0.7 percent zinc, and small amounts of tin and vanadium. There are no visible reserves, but like the Prince Burhanuddin locality, it shows that mineralized quartz veins are present in the Chitral Slate.

\section{GAHIRAT LOCALITY}

The Gahirat locality is 2 miles ( $3.2 \mathrm{~km}$ ) east of Gahirat village on the right bank of Binatolanga Gol $200 \mathrm{ft}$ $(61 \mathrm{~m})$ above the stream level. A quartz vein $10 \mathrm{ft}(0.3 \mathrm{~m})$ thick containing scattered galena and stibnite is found in an interbedded sequence of marble and calcareous mica schist. The vein strikes N., $20^{\circ} \mathrm{E}$., parallel to the enclosing country rock, dips $75^{\circ} \mathrm{W}$., and is about $250 \mathrm{ft}$ $(76 \mathrm{~m})$ long. No analyses were made of the ore at this locality.

\section{DROSH SHISHI VALLEY AREA}

\section{GAWUCH GOL LOCALITY}

The Gawuch Gol locality is in a local, narrow shear zone in chlorite schist 1 mile $(1.6 \mathrm{~km})$ east of the Shishi River on the south side of the southernmost tributary to Gawuch Gol. In this area, the chlorite schist, which is part of the Devonian to Jurassic sequence, contains numerous sheared and altered zones a few inches $(\mathrm{cm})$ to $3 \mathrm{ft}(0.9 \mathrm{~m})$ wide which are probably related to the major fault zone (the Shishi fault) about $400 \mathrm{ft}(121 \mathrm{~m})$ downstream that separates the Reshun Formation from the Devonian to Jurassic rocks (pl. 1). Thin quartz veinlets one quarter of an inch to 2 inches $(0.6-5 \mathrm{~cm})$ wide in one of the shear zones contain traces of galena and secondary malachite and azurite. Analyses of the. ore-bearing quartz (J104) shows $150 \mathrm{ppm}$ silver, 3 percent copper, 0.5 percent lead and small amounts of antimony, zinc, and vanadium. The locality contains an interesting suite of metals but is of no apparent economic value.
KALDAM GOL LOCALITY

The Kaldam Gol locality is 3 miles $(4.8 \mathrm{~km})$ east of Drosh on the north side of Kaldam Gol, $100 \mathrm{ft}(30 \mathrm{~m})$ above the stream level. No prospecting work has been done. Chalcopyrite, galena, and pyrite, and secondary malachite are found in a brown-weathering breccia zone between a bed of white marble and siliceous siltstone. The marble and siltstone belong to the sequence of Devonian to Jurassic rocks, and, as in the Gawuch Gol locality, this ore-bearing zone is only about $300 \mathrm{ft}(91 \mathrm{~m})$ east of the major fault separating Cretaceous rocks from Devonian to Jurassic rocks, and is probably related to it. The ore-bearing brecciated zone is $8 \mathrm{ft}(2.4 \mathrm{~m})$ wide and is strongly mineralized for the first $2 \mathrm{ft}(0.6 \mathrm{~m})$ adjacent to the marble, beyond which the visible ore is distributed in patchy fashion. At the eastern side of the 8-ft (2.4 m) ore-bearing breccia zone, the adjacent siltstone also is mineralized with thin stringers and veinlets of very finegrained chalcopyrite, galena, and pyrite. The mineralized breccia zone was traced to the northeast for $150 \mathrm{ft}$ $(46 \mathrm{~m})$ and for about the same distance to the southwest, as far as the cliff on the south side of Kaldam Gol where the zone has narrowed to a thickness of $1 \mathrm{ft}(30 \mathrm{~cm})$. Analysis of the "high grade" ore adjacent to the marble (SJ141) shows 8.9 percent copper, 39.5 percent lead, 5.6 percent antimony, 0.17 percent silver, and $4.3 \mathrm{ppm}$ gold. Analysis of a chip sample (J144b) across the entire 8-ft $(2.4 \mathrm{~m})$ zone shows 2.6 percent copper, less than 0.5 percent lead and antimony, less than 0.001 percent silver, and less than $0.05 \mathrm{ppm}$ gold. From the surface exposures, the ore reserve is estimated to be on the order of several hundred tons.

\section{COPPER LOCALITIES IN MAFIC ROCKS AND GREENSCHIST}

Many copper showings are found in the volcanic greenstone and amphibolite of the Drosh-Shishi Valley area, in the greenschist unit of the Koghozi area, and in the amphibolite of the Momi area.

The copper occurs as chalcopyrite and in small local veins and shear zones with or without quartz or calcite as associated vein minerals. All the localities reveal themselves by the conspicuous green or occasionally blue stain, due to secondary malachite and azurite, on the outcrop. In many localities, these secondary minerals are the only copper minerals visible.

Under the microscope, most of the rocks containing accessory chalcopyrite are seen to be volcanic in origin, and the chalcopyrite is in irregular grains surrounded by the unaltered volcanic matrix. The chalcopyrite is not evenly distributed throughout the rock, but is scattered along certain laminae. It is not associated with vein minerals such as quartz or calcite, nor with cracks, seams, or veinlets. Secondary malachite and azurite, 
associated with calcite, are seen in cracks and veinlets, but the chalcopyrite in these specimens is interstitial and independent of veins and cracks. The chalcopyrite is, therefore, considered to be a primary accessory mineral. The copper content, as estimated under the microscope and at the outcrop, is in most samples less than 1 percent. Many of the copper localities, however, do consist of small veins and fractures, or small shear zones, and most of these probably represent local migration of primary copper as a result of deformation and metamorphism.

The localities listed below are all similar in occurrence, as described above; therefore, they are not discussed individually in any great detail. The locations, identified by location number, are shown in figure 4.

\section{DROSH-SHISHI VALLEY AREA}

J102. - One quarter mile $(0.4 \mathrm{~km})$ south of Shishi River up a small creek opposite Shishi Village. Lens-shaped area containing calcite, malachite, and disseminated fine-grained black unidentified sulfide in porphyritic volcanic greenstone. Lens is $8 \mathrm{ft}(2.4 \mathrm{~m})$ long, 18 inches $(46 \mathrm{~cm})$ wide, and pinches out at both ends. Analysis: 7 percent copper, $15 \mathrm{ppm}$ silver, and small amounts of other metals.

J148a-f.-Opposite Pursat village on the Shishi River road, 4 miles $(6.4 \mathrm{~km})$ northeast of Drosh. Six area-chip samples from areas of unaltered volcanic greenstone. Copper ranges from 70 to $500 \mathrm{ppm}$. Smaller amounts of chromium, nickel, lead, and other metals are also present. The copper content, although higher than the average mafic volcanic rock, is too low to be considered as a potential source of copper.

SJ38. - Two tenths of a mile $(0.3 \mathrm{~km})$ southeast of J102. Phyllitic greenstone stained with malachite along a zone $8 \mathrm{ft}(2.4 \mathrm{~m})$ long and 6 inches $(15 \mathrm{~cm})$ wide.

SJ39. $-200 \mathrm{ft}(61 \mathrm{~m})$ from SJ38. Volcanic greenstone stained with malachite along a zone $10 \mathrm{ft}(3 \mathrm{~m})$ long and 3 to 4 inches $(8-10 \mathrm{~cm})$ thick.

SJ44.-One half mile $(0.8 \mathrm{~km})$ south of J102. Float block of fine-grained porphyritic olivine basalt containing malachite stains on weathered surface. Analysis shows 7 percent copper, $30 \mathrm{ppm}$ silver, and small amounts of other metals.

SJ49.-Drosh Gol, 0.6 mile $(1 \mathrm{~km})$ east of Drosh. Maroon porphyritic olivine basalt containing malachite in patches and associated with quartz and calcite in hairline cracks and seams. Analysis shows $1,000 \mathrm{ppm}$ copper, and smaller amounts of other metals.

SJ193. - Beorai Gol, 3.5 miles $(5.6 \mathrm{~km})$ south of Drosh. Pyrite and chalcopyrite disseminated in carbonate veinlets in gray, fine-grained, altered andesitic volcanic flow. Analysis shows only traces of copper and other metals.

SJ205.-Gawuch Gol, 1 mile $(1.6 \mathrm{~km})$ east of Tar village on Shishi River. Malachite stains along foliation surfaces of black, fissile, fine-grained quartzitic greenstone. Pyrite and chalcopyrite along hairline seams and disseminated along quartz-rich millimeter-sized layerlets. Analysis shows 500 ppm copper and only small amounts of other metals.

\section{KOGHOZI AREA}

J122d. - Along canal, 0.5 mile $(0.8 \mathrm{~km})$ southwest of Koghozi, $200 \mathrm{ft}(61 \mathrm{~m})$ above Mastuj road. Fine-grained albite-quartz-epidote-chlorite schist containing accessory chalcopyrite in irregular grains scattered through rock. Malachite stains in calcite veinlets. Outlines of original feldspar phenocrysts indicate rock was originally volcanic flow. Analysis shows 1,000 ppm copper and smaller amounts of other metals.

$S J 154$. - Along Mastuj road, 0.2 mile $(0.3 \mathrm{~km})$ north of Golen Gol. Pale-green, fine-grained, siliceous greenstone containing disseminated pyrite, magnetite, and possible chalcopyrite. Analysis shows only traces of copper and other metals.

SJ156. - On Mastuj road across from Khamkoru, 3 miles $(4.8 \mathrm{~km})$ northeast of Koghozi. Malachite staining in thin quartz veinlets in greenschist. No sample taken.

$S J 165$. - Along Mastuj road, 1.25 miles $(2 \mathrm{~km})$ west of Koghozi. Rusty, altered, aphanitic, maroon volcanic flow containing abundant malachite staining. Analysis shows 1.0 percent copper, $0.2 \mathrm{ppm}$ gold, and small amounts of other metals.

\section{MOMI LOCALITY}

$J 137$ - On main footpath along Arkari Gol just south of Isi Gol, 3 miles $(4.8 \mathrm{~km})$ northwest of Momi. Foliated, fine-grained, malachite-stained, layered amphibolite containing accessory chalcopyrite along a brownstrained zone 1 inch wide parallel to layering. Chalcopyrite in anhedral irregular aggregates scattered throughout brown-strained zone and unrelated to veinlets or cracks. Chalcopyrite is rimmed by red hematite alteration, and this is cause of brown stain along zone. Analysis shows 1,000 ppm copper and traces of other metals.

AH46.-Same locality as J137. Malachite-stained, black, fine-grained amphibolite containing accessory chalcopyrite. Sample not analyzed. 


\section{OTHER MINERALIZED LOCALITIES}

Other mineralized localities scattered throughout the area are listed below. They are mainly small copper showings, but include a few lead and antimony showings and also altered, possibly mineralized, rock.

\section{KAFIRISTAN AREA}

Samples of altered rock, possibly mineralized, were collected from five places in the Birir Gol area. These are as follows:

$J 44 a, b, c$. - Large boulder of rusty, altered quartzite containing layers of altered phyllite and a few quartz veins.

$J 48 .-$ Quartz-carbonate veins, $3 \mathrm{ft}(0.9 \mathrm{~m})$ thick, in small fault zone in phyllite, $200 \mathrm{ft}(61 \mathrm{~m})$ from main dolomite contact.

J52. - Stream boulder of altered silicified slate.

J145. - Green-stained dolomite. Suspected of being malachite.

Analyses of these specimens show no unusual amounts of metallic minerals, except J52 and J145, which contain 2.9 and $4.4 \mathrm{ppm}$ silver respectively. The green mineral in $\mathrm{J} 145$, which contains only $15 \mathrm{ppm}$ copper, is probably talc or chlorite.

In Rumbur Gol, 1 mile $(1.6 \mathrm{~km})$ north of Balanguru, scattered traces of a sulfide mineral-probably galena-were found in a 6 -inch $(15 \mathrm{~cm})$ quartz vein at the contact between the Reshun Formation and Chitral Slate. No analysis was made.

$A H$-l. - Bogosht Gol, 3.5 miles $(5.6 \mathrm{~km})$ south of the Hot Springs. Granite boulders containing malachite stains. Analysis shows $8.1 \mathrm{ppm}$ silver, 0.7 percent copper, 0.3 percent lead, and small amounts of antimony, zinc, and tin.

\section{DROSH-CHITRAL ROAD}

J143. - On Drosh-Chitral road at mouth of Shishi River on south side. Green coloring in brecciated dolomite. Brecciated zone is $2 \mathrm{ft}(0.6 \mathrm{~m})$ thick; brecciated dolomite contains patches of green mineral that looks like malachite. Analysis shows no unusual amounts of copper or other metallic minerals, except for 0.7 percent chromium. Mineral may be chromian chlorite.

J160. - South abutment of Shishi bridge. Malachite staining in tuffaceous greenstone. Sample not analyzed.

J149a.-On Drosh-Chitral road, 1 mile $(1.6 \mathrm{~km})$ north of Shishi River. Traces of chalcopyrite, pyrite, and malachite at edges of thin quartz veinlets cutting layer of amphibolite. Locality is in belt of interlayered granite and amphibolite. Analyses show $4.6 \mathrm{ppm}$ silver, $0.1 \mathrm{ppm}$ gold, 0.3 percent copper.

J150. - On Drosh-Chitral road, 2 miles $(3.2 \mathrm{~km})$ north of Shishi River. Traces of malachite and pyrite in cataclastic gneiss. Sample not analyzed.

\section{MUZHIGRAM}

J133. - Sulfur-stained black graphitic schist across Arkari Gol from Muzhigram was said to contain lead by the village people. Analyses of three types of altered rock from this locality show no unusual amounts of lead or other metallic minerals. The secondary sulfur bloom probably comes from the abundant authigenic pyrite in the graphitic schist.

\section{SHOGHOT}

$J 108$. - On Lutkho River road, 0.5 mile $(0.8 \mathrm{~km})$ east of Shoghot. Malachite stains in dolomite of Reshun Formation. Malachite, together with quartz, is in small irregular vugs 0.5 to 3 inches $(1-8 \mathrm{~cm})$ long. Outcrop contains five such stained areas. Sample not analyzed.

$A H 7$. On Lutkho River road, 1 mile $(1.6 \mathrm{~km})$ west of Shoghot. Malachite stains in quartzose schist. Analysis shows $15 \mathrm{ppm}$ silver, $0.4 \mathrm{ppm}$ gold, 1 percent copper, and small amounts of lead and antimony.

\section{MOGH}

J109. - On Lutkho River road, 1 mile $(1.6 \mathrm{~km})$ east of Mogh. Malachite and chalcopyrite in garnet-biotitequartz schist. Analysis shows $15 \mathrm{ppm}$ silver, $0.2 \mathrm{ppm}$ gold, 2 percent copper, and small amounts of lead.

\section{HOT SPRINGS}

J110.-One half mile $(0.8 \mathrm{~km})$ north of the Hot Springs. Altered granite sill, $60 \mathrm{ft}(18 \mathrm{~m})$ above cool spring and along line of springs. Analysis shows no unusual metallic content.

\section{NONMETALLIC MINERAL RESOURCES}

MARBLE, LIMESTONE, AND DOLOMITE

Marble, limestone, and dolomite are widespread in the Chitral area. The marble of the Reshun Formation crops out in three wide bands for the full length of the area, and in the Pasti-Reshun area unmetamorphosed limestone, and dolomite, interbedded with shale, constitute the bulk of the Devonian to Jurassic rock sequence. These rocks are available for use as a building stone, lime, crushed stone, agricultural limestone, portland cement, and for many other uses. However, because of the remoteness and inaccessibility of the area and the scarcity of fuel, this source is not likely to be exploited in the foreseeable future.

White, fine-grained marble suitable for building stone is available in large quantity at Gahirat, which is on the main road. Other marble localities are in Rumbur, Bumboret, and Birir Gols of Kafiristan; in Chitral Gol, and at Shoghot on the Lutkho River road. Marble, limestone, and dolomite very likely suitable for Portland Cement 
also are obtainable at Gahirat in the outcrops composed of interbedded marble and calcareous phyllite. Probably the best source of supply for the making of Portland Cement is the Reshun area, where unlimited supplies of interbedded limestone and shale are available. Suitable material for crushed stone, lime, and agricultural limestone is available from almost any of the numerous outcrops of marble, limestone, or dolomite in the area.

No commercial limestone industry presently exists in Chitral. However, marble is used locally for building stone and some lime is produced by local villagers for use as whitewash and in agriculture. In Chitral and Drosh, government buildings, resthouses, schools, and a few privately owned buildings are made of locally quarried marble blocks. Marble building blocks also are used in bridge abutments, retaining walls, and as protective walls along riverbanks.

\section{GRANITE BUILDING STONE}

Granite, suitable for building stone, is available in considerable quantities from the Koghozi granite. Two sources close to road transportation are 2 miles $(3.2 \mathrm{~km})$ east of Gahirat, and in Golen Gol, 2 miles $(3.2 \mathrm{~km})$ east of Koghozi. This latter locality is 1 mile $(1.6 \mathrm{~km})$ east of the Chitral-Mastuj road. Granite is used locally for building stone on a small scale, but marble and limestone are preferred because the latter are softer and, therefore, more easily shaped.

\section{PEGMATITE}

Feldspar-quartz-muscovite pegmatites are found sparingly in the Koghozi granite, the Shishi Valley granite, and in the metamorphic rocks along the Lutkho River between Mogh and the Hot Springs. They are all small and of no commercial value. A typical pegmatite crops out on the steep slope across the Lutkho River from Mogh. It is $11 \mathrm{ft}(3.3 \mathrm{~m})$ long, $6 \mathrm{ft}(1.8 \mathrm{~m})$ wide, is parallel to the foliation of the enclosing schist, and consists of quartz, orthoclase, muscovite, and some black tourmaline. Muscovite, in books as large as 2 inches $(5 \mathrm{~cm})$, and tourmaline form a thin selvage.

A larger quartz-feldspar pegmatite is 4 miles $(6.4 \mathrm{~km})$ north of Drosh, on the granite spur 1.6 miles $(2.6 \mathrm{~km})$ southwest of Loe Zom $(11,114 \mathrm{ft})(3,388 \mathrm{~m})$. It is $250 \mathrm{ft}$ $(76 \mathrm{~m})$ long, $50 \mathrm{ft}(15 \mathrm{~m})$ wide and the muscovite, in flakes and small books, is less than 1 inch $(2.5 \mathrm{~cm})$ in the long direction. Quartz and feldspar crystals are badly crushed. Scattered garnet is also present.

A group of three small pegmatites several miles northwest of the Hot Springs (fig. 3) area are being mined for mica and beryl on a small scale. These pegmatites are beyond the mapped area and were not visited.
TALC

One talc showing, of no commercial value, was found in Shishi Valley 0.3 mile $(0.5 \mathrm{~km})$ up a small creek from Tar village. Pale-green talc occupies a small shear zone in chlorite schist and calcareous schist. The talc is 15 inches $(38 \mathrm{~cm})$ thick and extends for $100 \mathrm{ft}(30 \mathrm{~m})$ upslope, at which point the shear zone narrows to a single fracture. Two other narrow shears filled with talc are nearby.

\section{PHOSPHATE}

A systematic search for phosphate was not possible in the time available. However, field tests were made by using a solution of ammonium molybdate and nitric acid on a few of those rocks most likely to contain phosphate. These include rocks from the limestone and shale sequence in the Pasti area and the Cretaceous limestone and shale south of Drosh. The results are outlined below:

Pasti area

Sarikol Shale

1. Black, indurated, thin-bedded shale. No phosphate reaction. No fizz with acid test solution. Evidently no carbonate present.

2. Black, indurated, thin-bedded shale. Same results as (1) above.

3. Brown-weathering, black, calcareous shale. Test solution turned faint yellow indicating traces of phosphate.

4. Calcareous sandstone. No phosphate reaction. Other Devonian to Jurassic rocks

5. Very slightly calcareous sandstone. No phosphate reaction.

6. Gray coral limestone. Test solution turned faint yellow indicating traces of phosphate.

7. Similar gray coral limestone, 2 miles $(3.2 \mathrm{~km})$ distant from (6) above. Test solution turned faint yellow indicating traces of phosphate.

Cretaceous limestone from Drosh area

8. Black, fissile, shaly limestone. No phosphate reaction.

9. Light-gray-weathering, black, organic calcareous shale. Test solution turned faint yellow indicating traces of phosphate.

10. Same rock type $10 \mathrm{ft}(3 \mathrm{~m})$ from $(9)$. No phosphate reaction.

The tests show small amounts of phosphate but no commercial amounts. However, the limestone south of Drosh and the limestone-shale sequence of the Pasti area appear to be likely sites for phosphate, so the superficial testing work as described above does not preclude the possible presence of phosphate in these areas. 


\section{CONCLUSIONS AND RECOMMENDATIONS}

Although the mineral prospects in the Chitral-Partsan area are not as hopeful as originally expected, certain areas are promising, and one locality, although small, contains very high values of gold and silver.

The places of high mineral potential are the vein deposits along the fault zones in the Awireth GolShoghot-Madashil area, and in the Shishi Valley area. Along these fault zones, the largest showings of copper, lead, and antimony are found; and in the Awireth Gol locality, the lead ore contains high values in gold and silver.

The Awireth Gol lead-gold-silver locality indicates the possibility that other larger deposits of this type of ore may be found along the major fault zone on the east side of Awireth Gol. A detailed search along this fault to the north and south of the Awireth Gol locality may disclose additional orebodies.

Northward along the same fault is the Madashil lead locality, so high-grade deposits also may be found anywhere along the interval of 7 miles $(11 \mathrm{~km})$ between the Awireth Gol locality and Madashil.

In the Shishi Valley, vein-type copper and lead showings were investigated in two localities 6 miles $(10 \mathrm{~km})$ apart situated adjacent to the fault on the east side of Shishi Valley. Detailed prospecting along this fault zone may reveal significant orebodies.

With regard to the Krinj mine area, the reserves are large enough to support continuous mining at the present modest rate for many years. However, the possibilities for expanding the operation into a major mining industry are small. Such an expansion probably is not economically attractive in view of the remoteness of the area, difficulty of transportation, lack of large reserves, and absence of significant amounts of byproduct metals in the antimony ore. Nevertheless, in order to put the present mining operation on a firmer footing, detailed topographic maps should be made of the surface area, as well as precise underground maps of the two main adits and of the numerous smaller underground workings. When this is accomplished, the locations of the adits and smaller workings will be known with respect to one another and to the surface. The sinuosities and irregularities of the main antimony vein can then be plotted accurately, and this information will allow the systematic development of the mine and help in predicting where more ore is likely to be found.

The copper-bearing mafic rocks and greenschists-located mainly in the Drosh area-appear to be too low in grade to be considered as low-grade copper deposits.

Because the snow was heavy in the high mountains, the area between Chitral and the Hot Springs could not be investigated. Consequently, it is recommended that a traverse be made from Chitral northwestward across
Utak An (15,271 ft) (4,695 m) and down Monur-O-Gol to the Hot Springs.

The area up the Lutkho River northwest of the Hot Springs also was not covered in this investigation. The copper-lead locality at Imirdin, and the surrounding area, should be investigated. The mica-beryl deposits farther upstream also should be investigated.

\section{REFERENCES CITED}

Ali, S. I., 1951, Alluvial gold in Chitral State: Pakistan Geological Survey open-file report, $11 \mathrm{p}$.

Ali, S. T., 1949, Preliminary report on the economic mineral occurrences in parts of Lutkho, Turikho, Multkho, and Chitral districts of Chitral State, Northwest Frontier Province: Pakistan Geological Survey open-file report.

Bakr, M. A., 1965, Geology of parts of Trans-Himalayan region in Gilgit and Baltistan, West Pakistan: Pakistan Geological Survey Records, v. 11, pt. 3,17 p.

Coulson, A. L., 1940, The mineral resources of the North-West Frontier Province: India Geological Survey Records, v. 75, no. 2, 55 p.

Crookshank, H., 1951, A note on the working of antimony ore in Chitral, with appendices showing requirements of staff, stores, etc., and probable costs: Pakistan Geological Survey open-file report.

Fermor, L. L., 1922, General report [of the Geological Survey of India] for the year 1921: India Geological Survey Records, v. 54, pt. 1,67 p.

Hayden, H. H., 1915, Notes on the geology of Chitral, Gilgit, and the Pamirs: India Greological Survey Records, v. 45, pt. 4, p. 271-335.

Heron, A. M., 1950, Directory of the economic minerals of Pakistan: Pakistan Geological Survey Records, v. 1, pt. 2, 69 p.

Ivanac, J. F., Traves, D. M., and King, D., 1956, The geology of the NW portion of the Gilgit Agency: Pakistan Geological Survey Records, v. 8, pt. 2, 27 p. (including geological map 1:500,000).

McMahon, C. A., and Huddleston, W. H., 1902, Fossils from the Hindu Khoosh: Geological Magazine, v. 9, p. 3-8, 49-58a.

Matsushita, Susumu, and Huzita, Kazuo, eds., 1965, Geology of the Karakoram and Hindu Kush: Kyoto University Scientific Expedition to the Karakoram and Hindu Kush, 1955, Results, v. 7, 150 p.

Nath, Mukti, 1944, A report on the antimony ore in Chitral State: India Geological Survey open-file report, $8 \mathrm{p}$.

Pascoe, E. H., 1923, General report [of the Geological Survey of India] for the year 1922: India Geological Survey Records, v. 55, pt. 1, $51 \mathrm{p}$.

-1924, General report [of the Geological Survey of India] for the year 1923: India Geological Survey Records, v. 56, pt. 1, 64 p.

Rahman, A. Y. M. H., 1949, Report on the Drosh District, Chitral: Pakistan Geological Survey open-file report 539, 21 p.

Reed, F. R. C., 1911, Devonian fossils from Chitral, Persia, Afghanistan, and the Himalayas: India Geological Survey Records, v. 41, p. $86-114$, pl. 7,8 .

1922, Devonian fossils from Chitral and the Pamirs: India Geological Survey, Palaeontologia Indica, n.s., v. 6, Mem. 2, 167 p., $16 \mathrm{pl}$.

1925, Upper Carboniferous fossils from Chitral and the Pamirs: India Geological Survey, Palaeontologia Indica, n.s., v. 6, no. 4, 154 p., $10 \mathrm{pl}$.

Sondhi, V. P., 1942, Preliminary note on antimony in Chitral: India Geological Survey open-file report.

Stauffer, K. W., 1975, Reconnaissance geology of the Central Mastuj Valley, Chitral State, Pakistan: U.S. Geological Survey open-file report $75-556,51 \mathrm{p}$.

White, M. G., 1975, Copper, lead, zinc, antimony, and arsenic in Pakistan: U.S. Geological Survey open-file report 75-162, 39 p. 